\title{
The use of $\mathrm{NO}_{2}$ absorption cross section temperature sensitivity to derive $\mathrm{NO}_{2}$ profile temperature and stratospheric-tropospheric column partitioning from visible direct-sun DOAS measurements
}

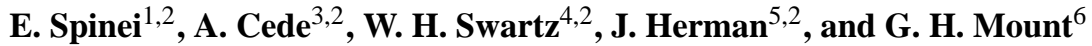 \\ ${ }^{1}$ ESSIC, University of Maryland, College Park, MD, USA \\ ${ }^{2}$ NASA/Goddard Space Flight Center (GSFC), Greenbelt, MD, USA \\ ${ }^{3}$ Universities Space Research Association, Greenbelt, MD, USA \\ ${ }^{4}$ Applied Physics Laboratory, The Johns Hopkins University, Laurel, MD, USA \\ ${ }^{5}$ University of Maryland, Baltimore County (UMBC), Catonsville, MD, USA \\ ${ }^{6}$ Laboratory for Atmospheric Research, Washington State University (WSU), Pullman, WA, USA
}

Correspondence to: E. Spinei (espinei@wsu.edu)

Received: 28 March 2014 - Published in Atmos. Meas. Tech. Discuss.: 6 June 2014

Revised: 18 October 2014 - Accepted: 28 October 2014 - Published: 9 December 2014

\begin{abstract}
This paper presents a temperature sensitivity method (TESEM) to accurately calculate total vertical $\mathrm{NO}_{2}$ column, atmospheric slant $\mathrm{NO}_{2}$ profile-weighted temperature $(T)$, and to separate stratospheric and tropospheric columns from direct-sun (DS), ground-based measurements using the retrieved $T$. TESEM is based on differential optical absorption spectroscopy (DOAS) fitting of the linear temperature-dependent $\mathrm{NO}_{2}$ absorption cross section, $\sigma(T)$, regression model (Vandaele et al., 2003). Separation between stratospheric and tropospheric columns is based on the primarily bimodal vertical distribution of $\mathrm{NO}_{2}$ and an assumption that stratospheric effective temperature can be represented by temperature at $27 \mathrm{~km} \pm 3 \mathrm{~K}$, and tropospheric effective temperature is equal to surface temperature within $3-5 \mathrm{~K}$. These assumptions were derived from the Global Modeling Initiative (GMI) chemistry-transport model (CTM) simulations over two northern midlatitude sites in 2011.

TESEM was applied to the Washington State University Multi-Function DOAS instrument (MFDOAS) measurements at four midlatitude locations with low and moderate $\mathrm{NO}_{2}$ anthropogenic emissions: (1) the Jet Propulsion Laboratory's Table Mountain Facility (JPLTMF), CA, USA $\left(34.38^{\circ} \mathrm{N} / 117.68^{\circ} \mathrm{W}\right)$; (2) Pullman, WA, USA $\left(46.73^{\circ} \mathrm{N} / 117.17^{\circ} \mathrm{W}\right)$; (3) Greenbelt, MD, USA $\left(38.99^{\circ} \mathrm{N} / 76.84^{\circ} \mathrm{W}\right)$; and (4) Cabauw, the Netherlands $\left(51.97^{\circ} \mathrm{N} / 4.93^{\circ} \mathrm{E}\right)$ during July 2007 , June-July 2009 , July-
\end{abstract}

August and October 2011, November 2012-May 2013, respectively. $\mathrm{NO}_{2} T$ and total, stratospheric, and tropospheric $\mathrm{NO}_{2}$ vertical columns were determined over each site.

\section{Introduction}

\section{$1.1 \mathrm{NO}_{2}$ importance}

Active nitrogen oxides $\left(\mathrm{NO}_{\mathrm{x}}=\mathrm{NO}+\mathrm{NO}_{2}\right)$ play an important role in atmospheric chemistry. They catalyze ozone destruction in the stratosphere, activate ozone production in the lower troposphere, and influence the $\mathrm{HO}_{\mathrm{x}}$ budget. $\mathrm{NO}_{2}$ itself is an air toxin that affects human health and is a precursor of acid rain in the lower troposphere (Mohnen, 1988). As a result, the vertical distribution of $\mathrm{NO}_{2}$ and its temporal variability is of great interest.

The main source of $\mathrm{NO}_{\mathrm{x}}$ in the stratosphere is nitrous oxide $\left(\mathrm{N}_{2} \mathrm{O}\right)$ transported from the troposphere, where about $10 \%$ of $\mathrm{N}_{2} \mathrm{O}$ is converted to $\mathrm{NO}_{\mathrm{x}}$. Stratospheric $\mathrm{NO}_{2}$ concentrations greatly depend on the solar actinic flux available for the $\mathrm{NO}_{\mathrm{x}}$ reservoir and $\mathrm{NO}_{2}$ photolysis. $\mathrm{N}_{2} \mathrm{O}_{5}$ is the most important nighttime off-polar $\mathrm{NO}_{\mathrm{x}}$ reservoir.

Tropospheric $\mathrm{NO}_{\mathrm{x}}$ mainly arises from fossil fuel combustion (vehicular, industrial, and air traffic), biomass burning (natural and anthropogenic), soil microbial production, 
lightning, and ammonia oxidation. Anthropogenic sources account for $\sim 75 \%$ of total global emissions, with a large uncertainty of $\sim 40 \%$ (Olivier et al., 1998). Vehicular emissions are estimated to contribute up to $50 \%$ of total $\mathrm{NO}_{\mathrm{x}}$ emissions and are characterized by high heterogeneity in space and time.

$\mathrm{NO}_{\mathrm{x}}$ is efficiently removed from the lower troposphere (lifetime $3-10 \mathrm{~h}$ in the tropics and summer northern midlatitudes, increasing to $48 \mathrm{~h}$ in winter at high latitudes) mainly by wet and dry deposition of $\mathrm{HNO}_{3}$ (Martin et al., 2003). The $\mathrm{NO}_{\mathrm{x}}$ lifetime in the free troposphere is longer (5-10 days), mainly due to lower humidity levels (Wenig et al., 2003). The lower troposphere $\mathrm{NO}_{\mathrm{x}}$ lifetime allows for transport on a regional scale (up to $100 \mathrm{~km}$ ). Long-range transport of $\mathrm{NO}_{\mathrm{x}}$ introduced into the free troposphere from the planetary boundary layer (PBL) has also been observed (Parrish et al., 2004; Wenig et al., 2003).

\section{$1.2 \quad \mathrm{NO}_{2}$ atmospheric profile modeling}

Figure 1 shows an example of $\mathrm{NO}_{2}$ winter and summer vertical profiles estimated by the Global Modeling Initiative (GMI) chemistry-transport model (CTM) (Duncan et al., 2007; Strahan et al., 2007) for the rural northwestern USA $\left(46^{\circ} \mathrm{N} / 117.5^{\circ} \mathrm{W}\right)$ in 2011 . GMI simulations of diurnal and seasonal variability of stratospheric $\mathrm{NO}_{2}$ column amounts are also shown in Fig. 2. Slow photolysis of $\mathrm{N}_{2} \mathrm{O}_{5}$ is responsible for the gradual increase in stratospheric $\mathrm{NO}_{2}$ concentrations during the day. After sunset, stratospheric $\mathrm{NO}_{2}$ concentrations rise sharply to their maximum due to NO oxidation by $\mathrm{O}_{3}$. The $\mathrm{NO}_{2}$ concentrations then gradually fall during the course of the night with a corresponding increase in $\mathrm{N}_{2} \mathrm{O}_{5}$ concentrations. After sunrise, stratospheric $\mathrm{NO}_{2}$ sharply drops to its minimum due to photolysis. The seasonal variability of stratospheric $\mathrm{NO}_{2}$ is also governed by the seasonal change in actinic flux (photolytic release of $\mathrm{NO}_{2}$ from $\mathrm{NO}_{\mathrm{x}}$ reservoirs). As expected, the GMI CTM model predicts maximum columns in summer and minimum in winter. Photolysis rates also define the altitude of the stratospheric $\mathrm{NO}_{2}$ peak and its width (Fig. 1). The stratospheric $\mathrm{NO}_{2}$ distribution tends to be broader in altitude in summer compared to winter.

\subsection{Differential optical absorption spectroscopy}

Passive differential optical absorption spectroscopy (DOAS) has been successfully applied since the 1970s to retrieve numerous trace gases, including $\mathrm{NO}_{2}$, from ground-based and satellite instruments (Noxon, 1975; Noxon et al., 1979; Mount et al., 1987; Solomon et al., 1987; Platt et al., 1979; Platt, 1994; Plane and Smith, 1995). While all passive DOAS measurements contain information about gas absorption at all atmospheric altitudes, different observation geometries have been developed to optimize the sensitivity of the pas- sive DOAS instruments to trace gas amounts located in various layers of the atmosphere.

The "traditional" ground-based DOAS technique employs a zenith-looking instrument to measure scattered sunlight (Noxon, 1975; Noxon et al., 1979), and is mainly sensitive to stratospheric and upper tropospheric absorbers, especially at large solar zenith angles $\left(\mathrm{SZA}>85^{\circ}\right)$. Vertical stratospheric $\mathrm{NO}_{2}$ profiles during sunset/sunrise were derived from zenith sky (e.g., McKenzie et al., 1991; Preston et al., 1997; Hendrick et al., 2004) and balloon DOAS measurements (e.g., Pommereau and Piquard, 1994; Butz et al., 2006; Kritten et al., 2010). Sunset and sunrise stratospheric $\mathrm{NO}_{2}$ columns have been measured since 1991 at multiple locations throughout the world as part of the international Network for the Detection of Atmospheric Composition Change (NDACC) (Hendrick et al., 2012). Sunrise/sunset $\mathrm{NO}_{2}$ vertical columns are typically interpolated to daylight hours using chemistry-transport models (Hendrick et al., 2004).

In the past two decades, ground-based multi-axis DOAS (MAX-DOAS) techniques have been developed, measuring scattered sunlight at multiple low elevation angles (Wagner et al., 2004, 2007, 2010; Heckel et al., 2005; Frieß et al., 2006; Sinreich et al., 2005; Li et al., 2008, 2010, 2013; Irie et al., 2008, 2009; Clémer et al., 2010). In contrast to the zenith DOAS, MAX-DOAS has significant sensitivity to tropospheric gas absorption due to increased photon path length through the lower troposphere.

Direct-sun/direct-moon (DS/DM) DOAS is equally sensitive to the stratospheric and tropospheric absorbers at SZA < $80^{\circ}$, and allows for very simple data interpretation (Cede et al., 2006; Herman et al., 2009; Wang et al., 2010; Spinei et al., 2010). This is due to the almost geometric calculation of DS/DM air mass factors (AMFs). Compared to MAXDOAS, it has a lower overall absorption sensitivity (Brewer et al., 1973; Cede et al., 2006) because of shorter path length in the atmosphere.

The DOAS technique is based on the modified BeerLambert law, which describes the spectral attenuation of electromagnetic radiation by molecular and aerosol absorption and scattering. DOAS retrieval consists of two steps. In the first step - spectral evaluation - differential slant column densities $(\triangle \mathrm{SCD})$ of the species of interest are calculated. This step is accomplished through simultaneous nonlinear least-squares spectral fitting of differential slant optical depths $(\tau)$ from various molecular and "pseudo-" absorbers (e.g., the Ring effect), a low-order polynomial (3-5) function, and an offset to the difference between the logarithms of the attenuated and reference spectra. The Fraunhofer line intensity of scattered solar light is not constant (Grainger and Ring, 1962). A decrease in the line depth and line broadening of up to a several percent is observed compared to the direct-sun spectra. This phenomenon is called the Ring effect and is mostly attributed to the rotational Raman scattering by the air molecules $\left(\mathrm{N}_{2}\right.$ and $\left.\mathrm{O}_{2}\right)$ (Kattawar et al., 1981; Fish and Jones, 1995; Chance and Spurr, 1997). To account 

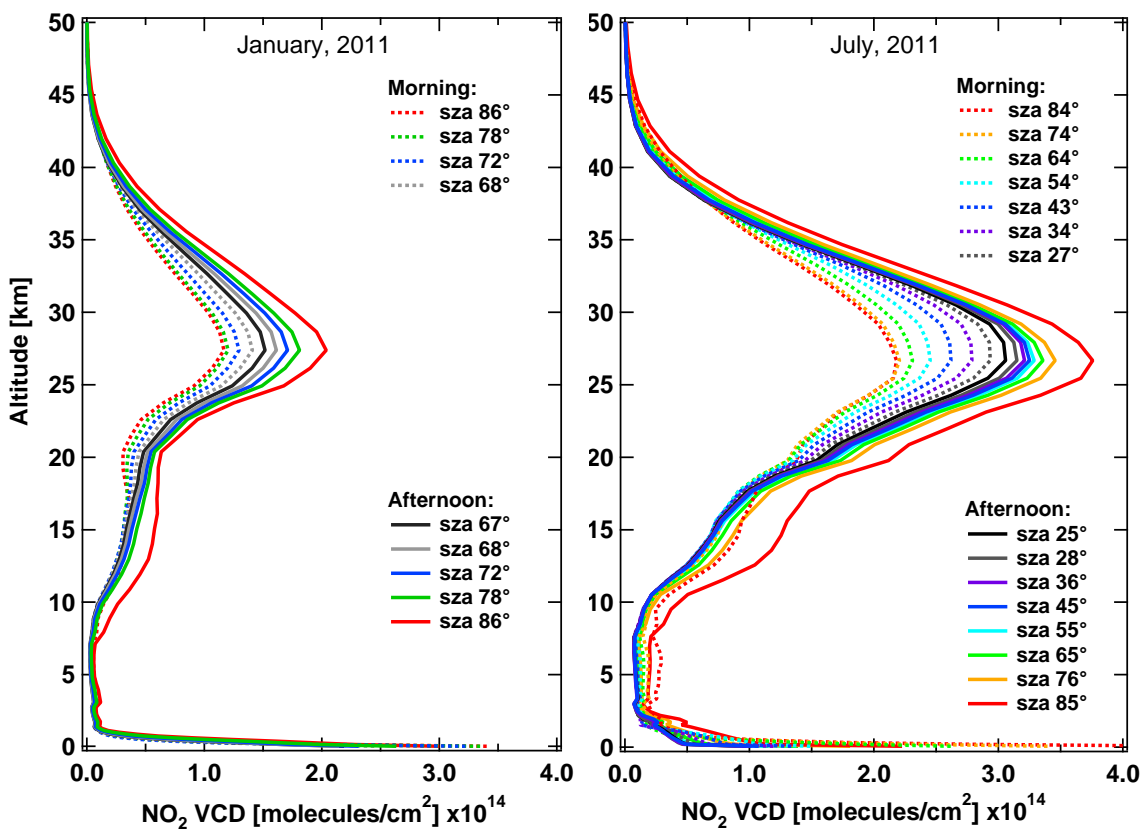

Figure 1. $\mathrm{NO}_{2}$ monthly-averaged hourly profile simulations by the GMI CTM for January (left panel) and July (right panel) 2011 over the northwestern USA $\left(46^{\circ} \mathrm{N} / 117.5^{\circ} \mathrm{W}\right)$. The time of the simulation is expressed as solar zenith angle (sza) in the morning or afternoon.

for variability of the Fraunhofer line intensity, a Ring spectrum is fitted as a "pseudo-absorption" cross section during the DOAS analysis. The second step of the analysis is conversion of the $\triangle \mathrm{SCD}$ into the vertical column density (VCD) of the molecular absorbers. Exact implementation of this last step depends on the observation geometry (e.g., DS, multiaxis or zenith sky DOAS).

$\mathrm{NO}_{2} \Delta \mathrm{SCD}$ is typically retrieved from visible DOAS measurements in the $400-500 \mathrm{~nm}$ wavelength range, where the larger spectral structure gives the greater sensitivity to $\mathrm{NO}_{2}$ absorption. The oxygen collision complex $\left(\mathrm{O}_{2} \mathrm{O}_{2}\right)$, water $\left(\mathrm{H}_{2} \mathrm{O}\right)$, and $\mathrm{O}_{3}$ also show spectrally varying absorptions in this wavelength window. Since spectral attenuation by $\mathrm{NO}_{2}$ and $\mathrm{O}_{3}$ takes place at different altitudes with different atmospheric temperatures, cross sections should be fitted at the corresponding slant-profile-weighted (effective) temperatures, $T$. These $T$ are determined from the $\mathrm{NO}_{2}$ volume mixing ratio profile (VMR) weighted by the air density profile in each atmospheric layer and average layer temperature from the bottom of the atmosphere (BOA) to the top of atmosphere (TOA). On most occasions, the gas effective temperature along the photon path is not known. Traditionally, either $\mathrm{NO}_{2}$ cross sections at a single profile-weighted temperature or two (stratospheric: $220 \mathrm{~K}$; tropospheric: $298 \mathrm{~K}$ ) temperatures are fitted. Usually, constant tropospheric and stratospheric temperatures are assumed throughout the measurement period. While this is never true during an extended observation period, it is used as a convenient approximation.

Accurate ground-based DOAS measurements are crucial for validation of $\mathrm{NO}_{2}$ satellite observations and es- timates CTMs. This paper presents a simple temperature sensitivity method (TESEM) to calculate $\mathrm{NO}_{2}$ slantprofile-weighted temperature, $T$, and total $\mathrm{NO}_{2} \mathrm{VCD}$ at $T$, and to separate stratospheric and tropospheric $\mathrm{NO}_{2} \mathrm{VCD}$ from DS DOAS ground-based visible-wavelength observations. TESEM is demonstrated using Washington State University Multi-Function DOAS instrument (MFDOAS) measurements at four locations at midlatitudes: the Jet Propulsion Laboratory's Table Mountain Facility (JPL-TMF), CA, USA $\left(34.38^{\circ} \mathrm{N} / 117.68^{\circ} \mathrm{W}\right)$; Pullman, WA, USA $\left(46.73^{\circ} \mathrm{N} / 117.17^{\circ} \mathrm{W}\right)$; Greenbelt, MD, USA $\left(38.99^{\circ} \mathrm{N} / 76.84^{\circ} \mathrm{W}\right)$; and Cabauw, the Netherlands $\left(51.97^{\circ} \mathrm{N} / 4.93^{\circ} \mathrm{E}\right.$ ) (see Table 1 during summer, fall, and winter months).

The paper is organized into the following sections. Section 2 describes $\mathrm{NO}_{2}$ cross section temperature dependence and DOAS retrieval of $\triangle \mathrm{SCD}$ at the slant-profile-weighted $T$. Section 3 lays out background for temperature sensitivity method to separate stratospheric and tropospheric $\mathrm{NO}_{2} \mathrm{SCD}$ based on the derived $\mathrm{NO}_{2}$ slant $T$. Section 4 evaluates stratospheric and tropospheric $\mathrm{NO}_{2} T$ using $\mathrm{NO}_{2}$ profile simulations by the GMI CTM. Section 5 briefly describes the MFDOAS instrument and measurements used in this study. The error budget is presented in Sect. 6. Section 7 presents results from four field campaigns with moderate-high and low $\mathrm{NO}_{2}$ pollution levels. Finally, Sect. 8 focuses on conclusions. 
Table 1. Summary of TESEM to calculate total VCD at $T$ and separate it into $\mathrm{VCD}^{\mathrm{TROP}}$ and $\mathrm{VCD}^{\mathrm{STRAT}}$.

\begin{tabular}{|c|c|c|c|}
\hline Step & Equation/method & & Important parameters \\
\hline \multirow{2}{*}{$\begin{array}{l}\text { 1. DOAS fitting of } \mathrm{NO}_{2} \\
\text { abs. cross section linear } \\
\text { model: constant }\left(\sigma_{0}\right) \\
\text { and slope }(\alpha)\end{array}$} & $\begin{array}{l}\text { Nonlinear least-squares fitting } \\
\text { (QDOAS in this study) }\end{array}$ & $\triangle \mathrm{SCD}$ & $\begin{array}{l}\text { - differential slant column density at actual atmospheric slant- } \\
\left.\text { profile-weighted temperature [molecule } \mathrm{cm}^{-2}\right]\end{array}$ \\
\hline & $\Delta \mathrm{SCD}=\mathrm{SCD}-\mathrm{SCD}^{\mathrm{REF}}$ & $\begin{array}{l}\Delta \mathrm{SCDT}_{\alpha} \\
\mathrm{SCD}\end{array}$ & $\begin{array}{l}=\mathrm{SCD} \\
-\mathrm{NO}_{2} \text { column along average photon path in the measured spec- } \\
\text { trum }\left[\text { molecule } \mathrm{cm}^{-2}\right]\end{array}$ \\
\hline \multirow{2}{*}{$\begin{array}{l}\text { 2. Estimation of total } \mathrm{NO}_{2} \\
\mathrm{SCD} \text { in the reference spec- } \\
\text { trum }\end{array}$} & $\begin{array}{l}\mathrm{MLE} \text { at } \mathrm{SZA}<75^{\circ} \\
\min \triangle \mathrm{SCD} \text { at } \triangle \mathrm{AMF} \text { correspond to } \mathrm{VCD} \approx \mathrm{VCD}^{\mathrm{REF}}\end{array}$ & $\begin{array}{l}\mathrm{SCD}^{\mathrm{REF}} \\
\mathrm{VCD}^{\mathrm{REF}}\end{array}$ & $\begin{array}{l}\text { - total SCD in the reference spectrum }\left[\text { molecule } \mathrm{cm}^{-2}\right] \text {; } \\
\text { - vertical column density in the reference spectrum; }\end{array}$ \\
\hline & $\mathrm{SCD}^{\mathrm{REF}}=\mathrm{VCD}^{\mathrm{REF}} \cdot \mathrm{AMF}^{\mathrm{REF}}$ & $\mathrm{AMF} F^{\mathrm{REF}}$ & $\begin{array}{l}\text { - air mass factor of the average photon path in the reference } \\
\text { spectrum }\end{array}$ \\
\hline \multirow{7}{*}{$\begin{array}{l}\text { 3. Estimation of strato- } \\
\text { spheric } \mathrm{NO}_{2} \mathrm{SCD} \text { in the } \\
\text { reference spectrum }\end{array}$} & $\begin{array}{l}\text { Langley plot at } \mathrm{SZA}<75^{\circ}\left(\mathrm{VCD} \approx \mathrm{VCD}^{\mathrm{REF}}, T \approx T^{\mathrm{REF}}\right) \\
T \approx \Delta \mathrm{SCDT}_{\alpha} / \Delta \mathrm{SCD} ;\end{array}$ & $T$ & $\begin{array}{l}\text { - initial total slant } \mathrm{NO}_{2} \text { profile-weighted temperature }[\mathrm{K}] \text { for } \\
\text { measurements with } \mathrm{VCD} \approx \mathrm{VCD}^{\mathrm{REF}}, T \approx T^{\mathrm{REF}}\end{array}$ \\
\hline & $T^{\mathrm{STRAT}}=\mathrm{AMF} \cdot T_{27 \mathrm{~km}}$ & $T_{0 \mathrm{~km}}$ & - surface temperature $[\mathrm{K}]$ \\
\hline & $T^{\mathrm{TROP}}=\mathrm{AMF} \cdot T_{0} \mathrm{~km}$ & $T_{27 \mathrm{~km}}$ & - temperature at $27 \mathrm{~km}[\mathrm{~K}]$ \\
\hline & $\chi^{\mathrm{STRAT}}=\left(T-T^{\mathrm{TROP}}\right) /\left(T^{\mathrm{STRAT}}-\mathrm{T}^{\mathrm{TROP}}\right)$ & $\chi^{\text {STRAT }}$ & - stratospheric fraction of total SCD; \\
\hline & $\Delta \mathrm{SCD}^{\mathrm{STRAT}} \approx \Delta \mathrm{SCD} \cdot \chi^{\mathrm{STRAT}}$ & $T^{\mathrm{TROP}}$ & - slant tropospheric $\mathrm{NO}_{2}$ profile-weighted temperature $[\mathrm{K}]$; \\
\hline & $\mathrm{VCD}_{\mathrm{REF}}^{\mathrm{STRAT}}$ from MLE & & - slant stratospheric $\mathrm{NO}_{2}$ profile-weighted temperature $[\mathrm{K}]$; \\
\hline & $\mathrm{SCD}_{\mathrm{REF}}^{\mathrm{STRAT}}=\mathrm{VCD}_{\mathrm{REF}}^{\mathrm{STRAT}} \cdot \mathrm{AMF}_{\mathrm{REF}}^{\mathrm{STRAT}}$ & $\begin{array}{l}\triangle \mathrm{SCD}^{S T R A I} \\
\mathrm{VCD}_{\mathrm{REF}}^{\mathrm{STRAT}}\end{array}$ & $\begin{array}{l}\text { - stratospheric SCD }\left[\text { molecule } \mathrm{cm}^{-2}\right] \\
\text { - stratospheric VCD in the reference spectrum } \\
{\left[\text { molecule } \mathrm{cm}^{-2} \text { ] }\right.}\end{array}$ \\
\hline $\begin{array}{l}\text { 4. Estimation of slant } \mathrm{NO}_{2} \\
T^{\mathrm{REF}}\end{array}$ & $T^{\mathrm{REF}}=\frac{\mathrm{SCD}_{\mathrm{STRAT}}^{\mathrm{REF}} \cdot T_{\mathrm{STRAT}}^{\mathrm{REF}}+\mathrm{SCD}_{\mathrm{TROP}}^{\mathrm{REF}} \cdot T_{\mathrm{TROP}}^{\mathrm{REF}}}{\mathrm{SCD}^{\mathrm{REF}}}$ & $T^{\mathrm{REF}}$ & $\begin{array}{l}\text { - total slant } \mathrm{NO}_{2} \text { profile-weighted temperature in reference } \\
\text { spectrum }[\mathrm{K}] ;\end{array}$ \\
\hline 5. Estimation of $T$ & $T=\frac{\Delta \mathrm{SCDT}_{\alpha}+\mathrm{SCD}^{\mathrm{REF}} \cdot T^{\mathrm{REF}}}{\mathrm{SCD}^{\mathrm{REF}}+\Delta \mathrm{SCD}}$ & $T$ & $\begin{array}{l}\text { - final total slant } \mathrm{NO}_{2} \text { profile-weighted temperature in reference } \\
\text { spectrum for all measurements }[\mathrm{K}] \text {; }\end{array}$ \\
\hline \multirow{2}{*}{$\begin{array}{l}\text { 6. Estimation of strato- } \\
\text { spheric and tropospheric } \\
\text { VCD }\end{array}$} & $\chi^{\text {STRAT }}=\frac{T-T^{\text {TROP }}}{T^{\text {STRAT }}-T^{\text {TROP }}} ; \chi^{\text {TROP }}=1-\chi^{\text {STRAT }}$ & $\mathrm{VCD}^{\mathrm{STRAT}}$ & - stratospheric $\mathrm{NO}_{2} \mathrm{VCD}$, [molecule $\mathrm{cm}^{-2}$ ]; \\
\hline & $\begin{array}{l}\mathrm{SCD}^{\mathrm{STRAT}}=\left(\mathrm{SCD}^{\mathrm{REF}}+\Delta \mathrm{SCD}\right) \cdot \chi^{\mathrm{STRAT}} \\
\mathrm{VCD}^{\mathrm{STRAT}}=\mathrm{SCD}^{\mathrm{STRAT}} / \mathrm{AMF}^{\mathrm{STRAT}}\end{array}$ & VCD ${ }^{\mathrm{TROP}}$ & - tropospheric $\mathrm{NO}_{2} \mathrm{VCD}$, [molecule $\left.\mathrm{cm}^{-2}\right]$ \\
\hline
\end{tabular}

\section{Retrieval of total $\mathrm{NO}_{2} \Delta \mathrm{SCD}$ based on a linear $\mathrm{NO}_{2}$ temperature-dependent absorption cross section model}

$\mathrm{NO}_{2}$ is distributed at different altitudes from the surface to the upper stratosphere. As a result, passive DOAS instruments measure net attenuation of solar radiation by $\mathrm{NO}_{2}$ at significantly different temperatures. The cumulative absorption optical depth (OD) for a specific DOAS observation geometry can be described in terms of the $\mathrm{NO}_{2}$ profileweighted temperature along an average photon path (slant $T)$. Since passive DOAS observations contain this "built-in" information about $T$, accurate retrieval of $\mathrm{NO}_{2} \triangle \mathrm{SCD}$ requires knowledge of $T$.

Investigation of the temperature sensitivity of $\mathrm{NO}_{2}$ absorption in zenith sky measurements was first initiated by J. Noxon in the late 1970s and early 1980s (unpublished data). However, due to the low quality of the scanning grating instruments at that time, deriving $\mathrm{NO}_{2}$ temperaturedependence information from scattered sky measurements was not possible. As the scientific understanding of the radiative transfer improved (e.g., modeling of Ring spectra) along with the development of better instrumentation utilizing multiplexing detectors (photodiode arrays and CCDs) and the availability of higher-quality molecular absorption cross section laboratory measurements, fitted DOAS OD spectral residuals decreased to near the photon shot noise limits $\left(<5 \times 10^{-4}\right)$. At these low residual levels, zenith sky and MAX-DOAS measurements indeed reveal $\mathrm{NO}_{2}$ temperature sensitivity. This encouraged high-quality laboratory measurements of $\mathrm{NO}_{2}$ cross sections in the UV and visible parts of spectrum at different temperatures from $220 \mathrm{~K}$ to room temperatures (Harder et al., 1997; Vandaele et al., 1998). However, these laboratory $\mathrm{NO}_{2}$ absorption cross sections at $220 \mathrm{~K}$ and room temperature show high cross correlation. This cross correlation introduces errors in derived $\triangle \mathrm{SCD}$ due to instrumental noise and uncertainties in all fitted cross sections. Richter (1997) suggested reducing cross correlation through cross section "orthogonalization" by means of the Graham-Smith process. Where, an "orthogonalized" cross section at one temperature $T_{1}, \sigma^{\text {ortho }}\left(T_{1} \rightarrow T_{2}\right)$, relative to the cross section at a second temperature $T_{2}\left(\sigma_{T_{2}}\right)$, is equal to $\sigma_{T_{1}}$ minus $\sigma_{T_{2}}$ multiplied by a scaling factor (SF). The SF is numerically equal to the "DOAS fit value" of $\sigma_{T_{2}}$ "into" $\sigma_{T_{1}}$ in a specific fitting wavelength window. Simultaneous spectral fitting of $\sigma^{\text {ortho }}\left(T_{1} \rightarrow T_{2}\right)$ and $\sigma_{T_{2}}$ results in an approximation of the 1) "true" $\triangle \mathrm{SCD}$ at $T_{1}$ from $\sigma^{\text {ortho }}$ $\left(T_{1} \rightarrow T_{2}\right)$ fit, and 2) $\Delta \mathrm{SCD}$ from $\sigma_{T_{2}}$ fitting, $\Delta \operatorname{SCD}\left(\sigma_{T_{2}}\right)$, 


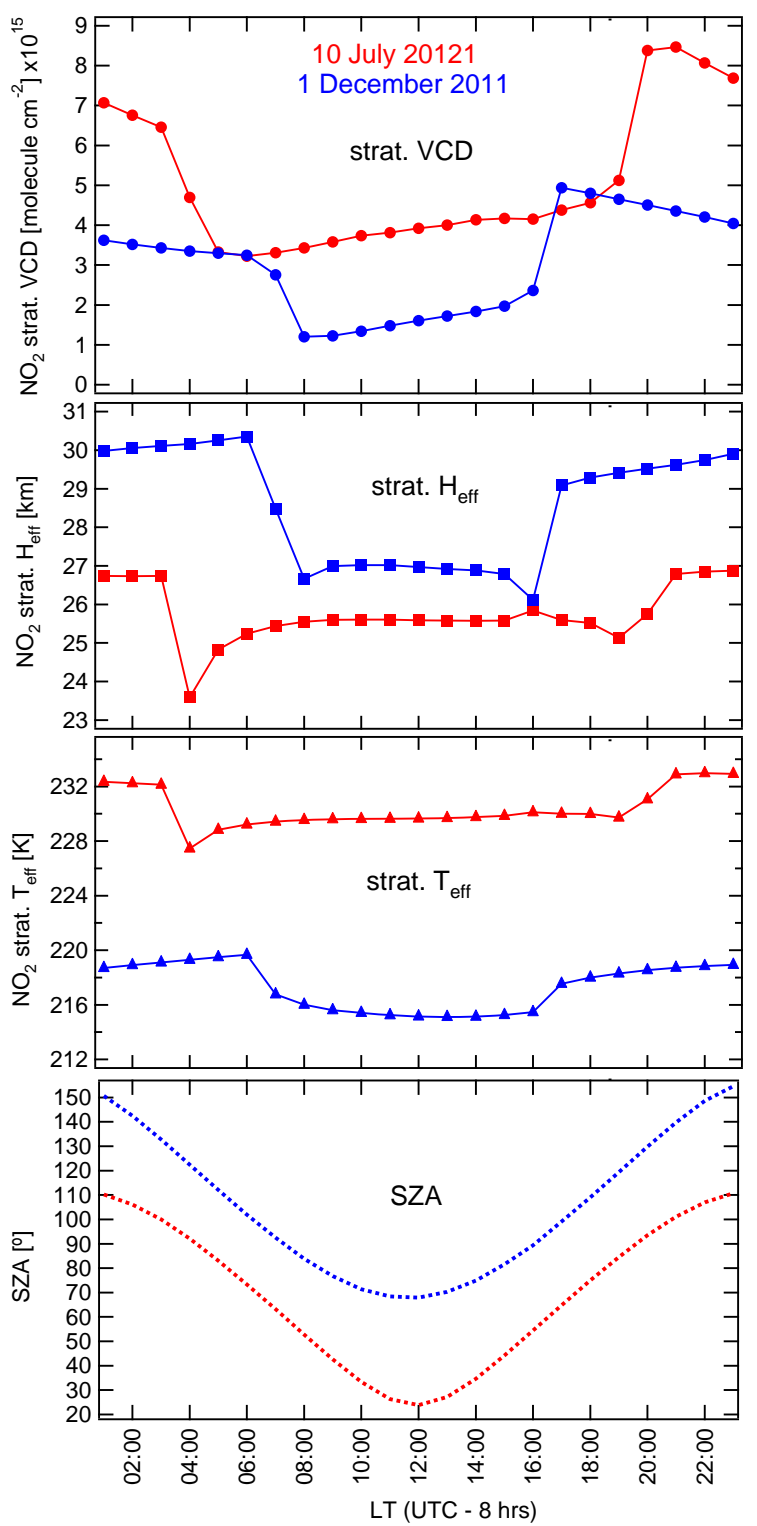

Figure 2. GMI CTM diurnal variation estimation of stratospheric $\mathrm{NO}_{2} \mathrm{VCD}, H_{\text {eff }}$, and $T_{\text {eff }}$ for 1 December 201139 (blue) and 10 July 2011 (red) over the northwestern USA $\left(46^{\circ} \mathrm{N} / 117.5^{\circ} \mathrm{W}\right)$. Solar zenith angles are also plotted to relate GMI estimations to DOAS measurements. Instantaneous GMI output temperatures at 00:00, 06:00, 12:00, and 18:00 UTC were interpolated on a $24 \mathrm{~h}$ grid.

which is equal to approximations of $\triangle \mathrm{SCD}$ at $T_{2}$ plus $\triangle \mathrm{SCD}$ at $T_{1}$ multiplied by $\mathrm{SF}\left(\Delta \mathrm{SCD}\left(\sigma_{T_{2}}\right)=\Delta \mathrm{SCD}_{T_{2}}+\Delta \mathrm{SCD}_{T_{1}}\right.$. $\mathrm{SF})$. Richter (1997) fitted $\sigma_{221}$ and $\sigma^{\text {ortho }}(293 \rightarrow 221)$ to derive tropospheric and stratospheric absorptions from zenith sky measurements using a modified Langley plot method.

We propose to derive $T$ and $\triangle \mathrm{SCD}$ at $T$ from DOAS observations by fitting the $\mathrm{NO}_{2}$ cross section temperaturedependence model.

\section{1 $\mathrm{NO}_{2}$ cross section temperature dependence}

The temperature-dependent $\mathrm{NO}_{2}$ cross section, $\sigma$, in $\mathrm{UV}$ and visible wavelength regions can be calculated at any $T$, using a linear regression model (Vandaele et al., 2003) (Eq. 1).

$\sigma(\lambda, T)=\sigma_{0}(\lambda)+\alpha(\lambda) \cdot\left(T-T_{0}\right)$,

where the constant $\sigma_{0}(\lambda)$ is the $\mathrm{NO}_{2}$ absorption cross section $\left[\mathrm{cm}^{2}\right.$ molecule $\left.{ }^{-1}\right]$ at temperature $T_{0}$ and wavelength $\lambda$ and $\alpha(\lambda)$ is a temperature-dependent coefficient describing the change in $\mathrm{NO}_{2}$ absorption cross section $\left[\mathrm{cm}^{2}(\mathrm{~K} \text { molecule })^{-1}\right]$ with temperature at wavelength $\lambda$. Figure 3 shows the high-resolution $\left(0.1 \mathrm{~cm}^{-1}\right.$; Vandaele et al., 2003) laboratory $\sigma_{0}(\lambda)$ at $273 \mathrm{~K}$ and $\alpha(\lambda)$ convolved with the MFDOAS instrument transfer function (FWHM $0.83 \mathrm{~nm} / 40.91 \mathrm{~cm}^{-1}$ at $450 \mathrm{~nm}$ ). While the atmospheric $\mathrm{NO}_{2}$ profile spans an altitude range with a significant pressure gradient, the pressure effect on $\sigma(\lambda)$ is not present at spectral resolution $\Delta \lambda>2 \mathrm{~cm}^{-1}(0.04$ at $450 \mathrm{~nm}$; Vandaele et al., 2003). Since most DOAS systems have much lower spectral resolution $(\Delta \lambda>0.4 \mathrm{~nm} / \mathrm{FWHM})$, the effect of pressure is ignored in this analysis.

\section{$2.2 \mathrm{NO}_{2}$ slant column density at $\mathrm{NO}_{2}$ profile- weighted temperature}

To improve the retrieval of $\mathrm{NO}_{2} \Delta \mathrm{SCD}$ from passive DOAS measurements, which are simultaneously affected by both stratospheric and tropospheric temperature regimes, we can derive slant $\mathrm{NO}_{2} T$ from the DOAS measurements themselves by fitting $\sigma$ linear regression model parameters $\sigma_{0}(\lambda)$ and $\alpha(\lambda)$. To simplify further notation, we assign $T_{0}=0 \mathrm{~K}$ and omit reference to $\lambda$.

The Beer-Lambert law written for a single absorber, $\mathrm{NO}_{2}$, with linear temperature-dependent $\sigma(T)$ and ideal groundbased DOAS measurements of solar monochromatic light is described according to Eq. (2):

$$
\begin{aligned}
\ln \left(\frac{I^{\mathrm{REF}}}{I}\right) & =\tau-\tau^{\mathrm{REF}} \\
& =\mathrm{SCD} \cdot\left[\sigma_{0}+\alpha \cdot T\right]-\mathrm{SCD}^{\mathrm{REF}} \cdot\left[\sigma_{0}+\alpha \cdot T^{\mathrm{REF}}\right] \\
& =\sigma_{0} \cdot \underbrace{\Delta \mathrm{SCD}}_{\text {DOAS fit result }} \\
& +\alpha \cdot \underbrace{\left[\mathrm{SCD}^{\mathrm{REF}} \cdot\left(T-T^{\mathrm{REF}}\right)+\Delta \mathrm{SCD} \cdot T\right]}_{\text {DOAS fit result }}
\end{aligned}
$$

where $I$ and $I^{\mathrm{REF}}$ are the measured intensities of an attenuated and a reference spectrum [counts s ${ }^{-1}$ ] at wavelength $\lambda[\mathrm{nm}]$, respectively; SCD and $\mathrm{SCD}^{\mathrm{REF}}$ are slant column densities of $\mathrm{NO}_{2}$ along an average photon path at observation and reference times, respectively [molecules $\mathrm{cm}^{-2}$ ]; and $T$ and $T^{\mathrm{REF}}$ are $\mathrm{NO}_{2}$ slant-profile-weighted temperatures at the observation and reference times, respectively $[\mathrm{K}]$. The photon path for each direct-sun measurement is described 


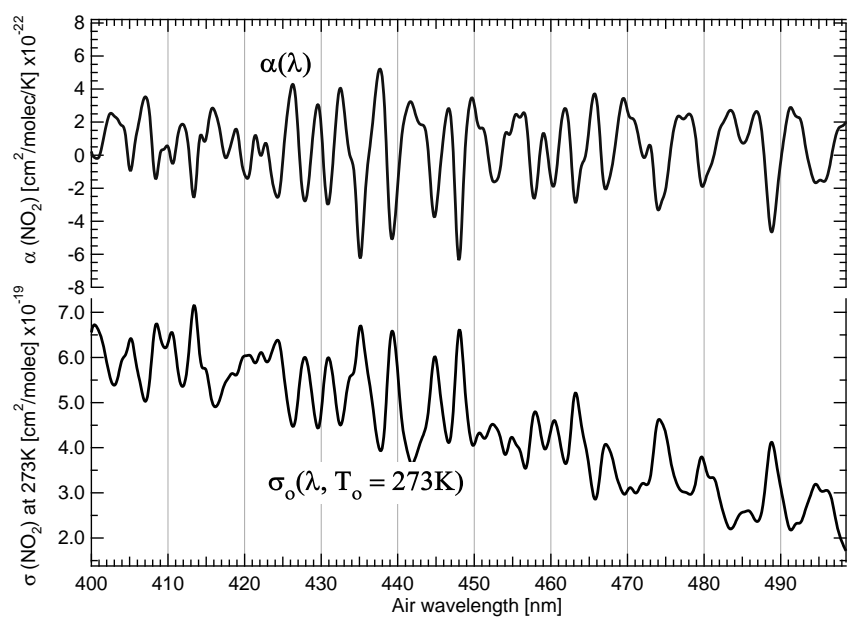

Figure 3. $\mathrm{NO}_{2}$ absorption cross section linear regression model parameters $\sigma_{0}(\lambda)$ and $\alpha(\lambda)$ for $T_{0}=273 \mathrm{~K}$ derived by Vandaele et al. (2003) and convolved with MFDOAS instrument transmission function $(\mathrm{FWHM}=0.83 \mathrm{~nm})$.

by an AMF and is defined by solar zenith angle, Earth's surface curvature, and, to a smaller degree, $\mathrm{NO}_{2}$ profile (at SZA $>80^{\circ}$; Cede et al., 2006).

Reference spectra are typically measured at the observation conditions with minimum photon path and $\mathrm{NO}_{2}$ total column. Therefore, the DOAS spectral fitting determines differential SCD $(\triangle \mathrm{SCD})$ at $T$, which is the difference between the SCD present at the observation and reference conditions.

Simultaneous DOAS fitting of OD due to $\sigma_{0}$ and $\alpha$ results in $\triangle \mathrm{SCD}$ and $\triangle \mathrm{SCD} T_{\alpha}=\left[\mathrm{SCD} \cdot T-\mathrm{SCD}^{\mathrm{REF}} \cdot T^{\mathrm{REF}}\right]$, respectively. This is an improvement on the currently used DOAS settings (see Introduction) to retrieve $\triangle \mathrm{SCD}$, since no prior assumption is made about the stratospheric-tropospheric $\mathrm{NO}_{2}$ profile partitioning or temperatures during the DOAS fitting step. Derived $\triangle \mathrm{SCD} T_{\alpha}$ is simply related to $T$.

\section{$2.3 \mathrm{NO}_{2}$ slant-profile-weighted temperature}

$\mathrm{NO}_{2}$ profile-weighted $T$ is an important quantity on its own, since it carries information about both tropospheric and stratospheric contributions. It can be determined from the DOAS fitted optical depth of the temperature coefficient, $\triangle \mathrm{SCD} T_{\alpha}$, as defined in Eq. (3):

$T=\frac{\Delta \mathrm{SCD} T_{\alpha}+\mathrm{SCD}^{\mathrm{REF}} \cdot T^{\mathrm{REF}}}{\Delta \mathrm{SCD}+\mathrm{SCD}^{\mathrm{REF}}}$.

$\mathrm{SCD}^{\mathrm{REF}}$ and $T^{\mathrm{REF}}$ are not known beforehand but can be approximated from the DS DOAS measurements themselves (see Sect. 3.1).
3 Separation of stratospheric and tropospheric $\mathrm{NO}_{2}$ SCD based on the derived $\mathrm{NO}_{2}$ slantprofile-weighted temperature

Since the vertical $\mathrm{NO}_{2}$ profile has mostly bimodal shape at distinctly different temperatures and altitudes, $T$ can be approximated as a sum of the stratospheric and tropospheric slant $T$ ( $T^{\text {STRAT }}$ and $T^{\text {TROP }}$ ) multiplied by their corresponding total column fractions ( $\chi$, Eq. 4).

$$
\begin{aligned}
T= & \chi_{\mathrm{STRAT}} \cdot T^{\mathrm{STRAT}}+\chi_{\mathrm{TROP}} \cdot T^{\mathrm{TROP}} ; \\
& \chi_{\mathrm{STRAT}}+\chi_{\mathrm{TROP}}=1 .
\end{aligned}
$$

After rearranging Eq. (4) we can estimate stratospheric $\left(\chi_{\mathrm{STRAT}}\right)$ and tropospheric $\left(\chi_{\mathrm{TROP}}\right)$ fractions of total SCD:

$\chi_{\mathrm{STRAT}}=\frac{T-T^{\mathrm{TROP}}}{T^{\mathrm{STRAT}}-T^{\mathrm{TROP}}}$.

Stratospheric and tropospheric SCD are subsequently determined by multiplying their corresponding fractions by the total SCD.

$$
\begin{aligned}
\mathrm{SCD}^{\mathrm{STRAT}}= & \mathrm{SCD} \cdot \chi_{\mathrm{STRAT}} ; \\
& \mathrm{SCD}^{\mathrm{TROP}}=\mathrm{SCD} \cdot\left(1-\chi_{\mathrm{STRAT}}\right) .
\end{aligned}
$$

Equations (3) and (5) show that accurate separation of stratospheric-tropospheric $\mathrm{NO}_{2}$ column requires knowledge of $\mathrm{NO}_{2} \mathrm{SCD}^{\mathrm{REF}}$ and $\mathrm{NO}_{2} T^{\mathrm{REF}}$ in the reference spectrum.

\subsection{Estimation of $\mathrm{NO}_{2} \mathrm{SCD}^{\mathrm{REF}}$ and $T^{\mathrm{REF}}$}

$\mathrm{SCD}^{\mathrm{REF}}$ can be estimated using theminimum Langley extrapolation method (MLE; Herman et al., 2009; see Eq. 7), which consists of linear extrapolation of the smallest measured $\triangle \mathrm{SCD}$ to $\mathrm{AMF}=0$. Where, $\mathrm{VCD}$ at the reference time $\left(\mathrm{VCD}^{\mathrm{REF}}\right)$ is equal to the slope of the linear regression line fitted to the smallest $\triangle \mathrm{SCD}$ at each SZA as a function of $\triangle \mathrm{AMF}\left(\mathrm{AMF}-\mathrm{AMF}^{\mathrm{REF}}\right)$ :

$$
\begin{aligned}
\Delta \mathrm{SCD}= & \Delta \mathrm{VCD} \cdot \mathrm{AMF} \\
& +\mathrm{VCD}^{\mathrm{REF}} \cdot\left(\mathrm{AMF}-\mathrm{AMF}^{\mathrm{REF}}\right) .
\end{aligned}
$$

Due to strong changes in $\mathrm{NO}_{2}$ stratospheric $\mathrm{VCD}$ at $\mathrm{SZA}>75^{\circ}$ and the main assumption of MLE that there are data with constant $\mathrm{VCD}=\mathrm{VCD}^{\mathrm{REF}}(\triangle \mathrm{VCD} \approx 0)$, only measurements at $\mathrm{SZA}<75^{\circ}$ are used to derive $\mathrm{VCD}^{\mathrm{REF}}$. To avoid errors associated with seasonal variability of $\mathrm{NO}_{2}$ VCD, MLE should be applied to data collected during the same season. One month of data is typically sufficient.

$T^{\mathrm{REF}}$ is harder to estimate since it requires prior knowledge of stratospheric and tropospheric $\mathrm{NO}_{2} \mathrm{SCD}$ in the reference spectrum. These columns can also be estimated from the data used in MLE analysis. For conditions when Langley plot assumptions apply ( $\mathrm{VCD} \approx \mathrm{VCD}^{\mathrm{REF}}$ and $T \approx T^{\mathrm{REF}}$ ) Eq. (3), simplifies to $T \approx \Delta \mathrm{SCD} T_{\alpha} / \Delta \mathrm{SCD}$. Thus stratospheric $\mathrm{SCD}$ in the reference spectrum $\left(\mathrm{SCD}_{\mathrm{REF}}^{\mathrm{STRAT}}\right)$ can be 
approximated using Eqs. (5) and (6) and the Langley plot. After $\mathrm{SCD}_{\mathrm{REF}}^{\mathrm{STRAT}}$ is estimated, the $T^{\mathrm{REF}}$ can be determined knowing stratospheric and tropospheric $\mathrm{NO}_{2}$ profile $T$ at the reference time $\left(T_{\mathrm{REF}}^{\mathrm{STRAT}}, T_{\mathrm{REF}}^{\mathrm{TROP}}\right)$

$$
\begin{aligned}
& T^{\mathrm{REF}}= \\
& \frac{\mathrm{SCD}_{\mathrm{REF}}^{\mathrm{STRAT}} \cdot T_{\mathrm{REF}}^{\mathrm{STRAT}}+\left(\mathrm{SCD}^{\mathrm{REF}}-\mathrm{SCD}_{\mathrm{REF}}^{\mathrm{STRAT}}\right) \cdot T_{\mathrm{REF}}^{\mathrm{TROP}}}{\mathrm{SCD}^{\mathrm{REF}}} .
\end{aligned}
$$

Accurate calculation of $T$ is now possible for all measurements using Eq. (3) and subsequent stratosphere-troposphere $\mathrm{NO}_{2}$ partitioning (SCD ${ }^{\mathrm{STRAT}} / \mathrm{SCD}^{\mathrm{TROP}}$ ) using Eqs. (5) and (6).

The only unknown parameters in Eqs. (5) and (8) are slant $T^{\mathrm{TROP}}, T^{\mathrm{STRAT}}, T_{\mathrm{REF}}^{\mathrm{STRAT}}$, and $T_{\mathrm{REF}}^{\mathrm{TROP}}$. These slant temperatures are related to vertical profile-weighted temperatures through the corresponding tropospheric and stratospheric AMFs (AMF ${ }^{\text {STRAT }}$ and $\mathrm{AMF}^{\mathrm{TROP}}$ ) normalized by total AMF:

$$
\begin{aligned}
T^{\mathrm{STRAT}}= & \mathrm{AMF}_{\text {norm }}^{\mathrm{STRAT}} \cdot T_{\text {vertical }}^{\mathrm{STRAT}} ; \\
& T^{\mathrm{TROP}}=\mathrm{AMF}_{\text {norm }}^{\mathrm{TROP}} \cdot T_{\text {vertical }}^{\mathrm{TROP}} .
\end{aligned}
$$

For DS $\mathrm{NO}_{2}$ measurements there is very little dependence of AMFs on $\lambda$ at most SZAs; therefore, slant $T$ are also wavelength independent. In addition, for $\mathrm{SZA}<75^{\circ}$, normalized $\mathrm{AMF}$ is $\approx 1$.

\section{Estimation of $\mathrm{NO}_{2}$ vertical profile-weighted temperatures based on GMI CTM simulations}

In this section we use $\mathrm{NO}_{2}$ profile simulations from the GMI CTM for two purposes: (1) to evaluate diurnal and seasonal variability of stratospheric and tropospheric vertical $\mathrm{NO}_{2}$ profile-weighted temperatures and heights, and (2) to demonstrate that vertical $T^{\text {TROP }}$ and $T^{\text {STRAT }}$ can be relatively well approximated from measured or modeled temperature profiles at specific altitudes (surface and $27 \mathrm{~km}$ ). GMI analysis results are shown for the grid cells encompassing Pullman, WA (northwestern USA, $46^{\circ} \mathrm{N} / 117.5^{\circ} \mathrm{W}$ ), and Cabauw, the Netherlands (northwestern Europe, $52^{\circ} \mathrm{N} / 5^{\circ} \mathrm{E}$ ).

The GMI CTM simulates the overall state of the stratosphere and troposphere. It accounts for most important chemical and physical processes (emissions, aerosol microphysics, chemistry, deposition, radiation, advection, and lightning $\mathrm{NO}_{\mathrm{x}}$ production; Duncan et al., 2007). The GMI chemistry couples the stratospheric chemical mechanism described by Douglass et al. (2004) with tropospheric $\mathrm{O}_{3}-\mathrm{NO}_{\mathrm{x}}-$ hydrocarbon chemistry derived from the Harvard GEOSChem model (Bey et al., 2001). It is driven by GEOS-5 meteorological fields (Rienecker et al., 2008) at a resolution of $2^{\circ}$ (latitude) $\times 2.5^{\circ}$ (longitude). The atmosphere is modeled on a vertical grid from the surface to $0.01 \mathrm{hPa}$, with 72 levels. Level heights range from $\sim 150 \mathrm{~m}$ in the PBL to $\sim 1 \mathrm{~km}$ in the free troposphere and lower stratosphere. Threedimensional $\mathrm{NO}_{2}$ fields were saved every hour to account for the diurnal variation of $\mathrm{NO}_{2}$, particularly in the stratosphere. Stratospheric profiles in this study are identified as profiles above $8 \mathrm{~km}$, and tropospheric - below $8 \mathrm{~km}$.

The center of mass of the $\mathrm{NO}_{2}$ profile from GMI CTM simulations can be defined as profile-weighted height $\left(H_{\text {eff }}\right)$, where the $\mathrm{NO}_{2} \mathrm{VMR}$ is weighted by the air density profile in each atmospheric GMI grid layer and average layer height. $T_{\text {eff }}$ is calculated in a similar manner. The subscript "eff" is used to distinguish vertical modeling results from other parameters. Figure 4 shows examples of stratospheric $\mathrm{NO}_{2}$ $H_{\text {eff }}$ and $T_{\text {eff }}$ calculated from GMI CTM estimations over the northwestern USA (cell center: $46^{\circ} \mathrm{N} / 117.5^{\circ} \mathrm{W}$ ) for 10 July and 1 December 2011.

Stratospheric $\mathrm{NO}_{2} H_{\text {eff }}$ has very small variability during daylight hours $\left(\mathrm{SZA}<80^{\circ}\right)$, ranging from 25 to $27 \mathrm{~km}$. It tends to be somewhat higher at night (by $1-3 \mathrm{~km}$ ), with a minimum around sunset/sunrise (Fig. 4). Change in stratospheric $T_{\text {eff }}$ during daylight hours is no more than $\pm 1 \mathrm{~K}$ during a particular day.

Figure 5 shows stratospheric and tropospheric $H_{\text {eff }}$ calculated from GMI estimations for the northwestern USA $\left(46^{\circ} \mathrm{N} / 117.5^{\circ} \mathrm{W}\right)$ with low anthropogenic emissions and for the heavily populated northwestern Europe with moderateto-high $\mathrm{NO}_{2}$ emissions $\left(52^{\circ} \mathrm{N} / 5^{\circ} \mathrm{E}\right)$ for the year 2011. As expected, tropospheric $\mathrm{NO}_{2}$ profile $H_{\text {eff }}$ is closer to the surface over strong emission sources $\left(52^{\circ} \mathrm{N} / 5^{\circ} \mathrm{E}\right)$ : $0.6 \pm 0.2 \mathrm{~km}$. A more homogeneous distribution within the lower troposphere is estimated by the GMI CTM over the low-emission region $\left(46^{\circ} \mathrm{N} / 117.5^{\circ} \mathrm{W}\right): 1 \pm 0.4 \mathrm{~km}$. The seasonal change in stratospheric $H_{\text {eff }}$ is relatively small $(25.4 \pm 1.8 \mathrm{~km}$ (2 standard deviations)). Seasonal actinic flux changes, however, result in larger variability in stratospheric $\mathrm{NO}_{2} T_{\text {eff }}$ (Fig. 4) at these latitudes, especially in winter (Fig. 6). This is mainly due to polar weather effects.

We used GMI CTM outputs to evaluate whether $\mathrm{NO}_{2}$ stratospheric and tropospheric $T$ can be estimated from temperature profiles (atmospheric soundings or model meteorological fields) at a specific altitude. Temperature at an average stratospheric $\mathrm{NO}_{2} H_{\text {eff }}$ of $25.4 \mathrm{~km}$ tends to be lower than the "true" modeled stratospheric $\mathrm{NO}_{2} T_{\text {eff }}$ by 2.9 and $5 \mathrm{~K}$ for the northwestern USA and northwestern Europe, respectively. This is probably the result of uncertainty in stratospheric lapse rate change around $25 \mathrm{~km}$ due to an $\mathrm{O}_{3}$ peak. Using the average temperature between 20 and $30 \mathrm{~km}$ reduces some noise but still produces an offset of $4 \mathrm{~K}$. Figure 5 shows the difference between $T_{\text {eff }}$ and temperature at $27 \mathrm{~km}$, which tends to have smaller errors in summer ( 1 to $2 \mathrm{~K}$ ) and a more significant error (up to $6 \mathrm{~K}$ ) in winter. Annual differences (2011) between stratospheric $T_{\text {eff }}$ and temperature at $27 \mathrm{~km}$ are $1 \pm 1.6 \mathrm{~K}$ (northwestern USA) and $2.8 \pm 3 \mathrm{~K}$ (northwestern Europe). Based on GMI simulations we conclude that temperature at $27 \mathrm{~km} \pm 3 \mathrm{~K}$ provides a good estimate of the $T_{\text {vertical }}^{\text {STRAT }}$ from April to October over midlati- 

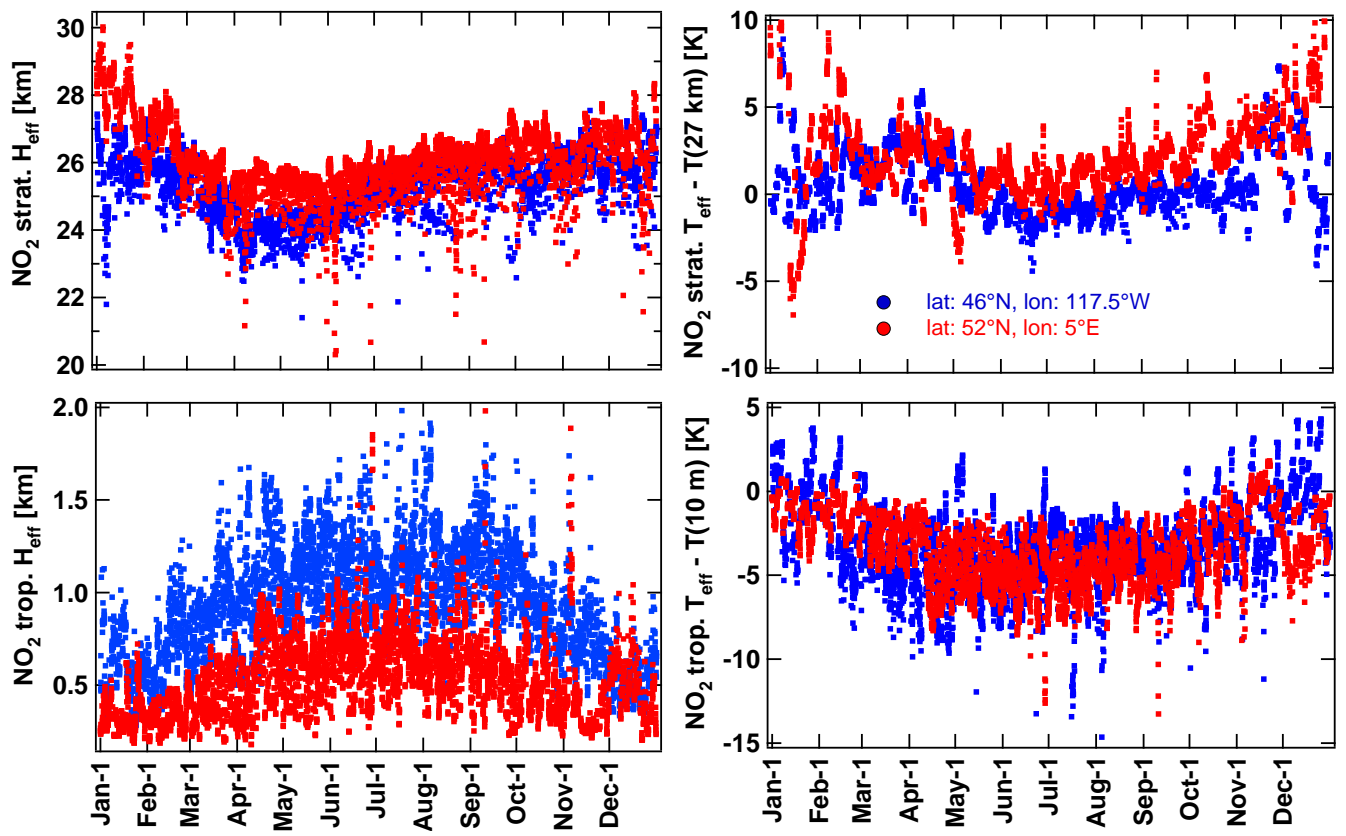

Figure 4. GMI CTM stratospheric $\mathrm{NO}_{2}$ columns estimations for 2011 over the northwestern USA (46 ${ }^{\circ} \mathrm{N} / 117.5^{\circ} \mathrm{W}$ : blue) and northwest Europe $\left(52^{\circ} \mathrm{N} / 5^{\circ} \mathrm{E}\right.$ : red). Seasonal stratospheric (upper left) and tropospheric (lower left) $\mathrm{NO}_{2}$ profile effective heights $\left(H_{\text {eff }}\right)$ are shown in the left panel. The differences between corresponding stratospheric $\mathrm{NO}_{2}$ profile effective temperatures $\left(T_{\text {eff }}\right)$ and temperature at $27 \mathrm{~km}$ are shown in the upper right panel. The differences between corresponding tropospheric $\mathrm{NO}_{2}$ profile effective temperatures $\left(T_{\mathrm{eff}}\right)$ and temperature at $10 \mathrm{~m}$ above the surface are shown in the lower right panel.
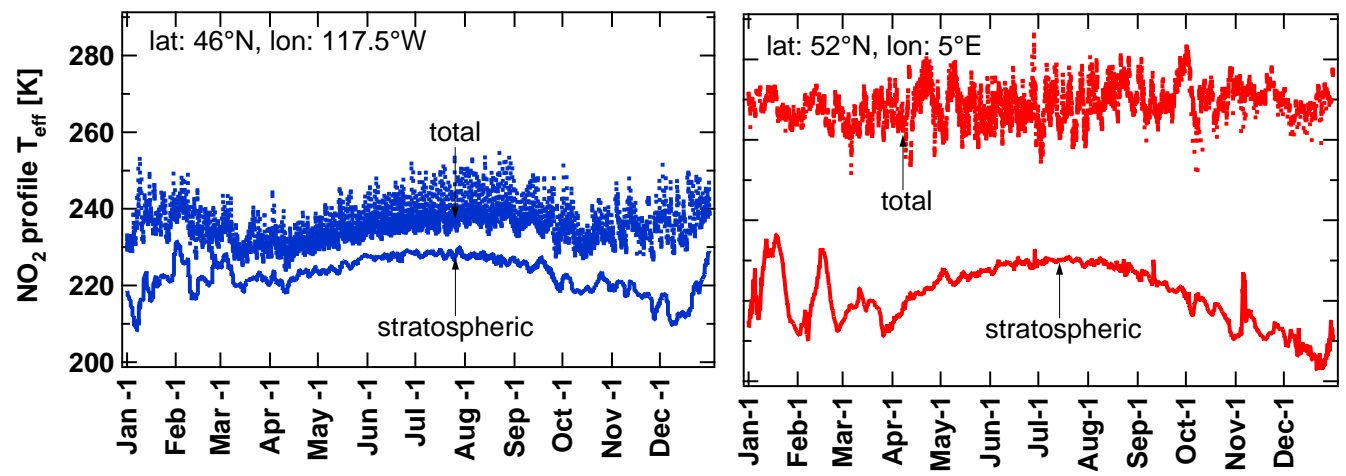

Figure 5. GMI stratospheric and total vertical $\mathrm{NO}_{2}$ profile effective temperatures for 2011 over the northwestern $\mathrm{USA}\left(46^{\circ} \mathrm{N} / 117.5^{\circ} \mathrm{W}\right.$, left $)$ and northwestern Europe $\left(52^{\circ} \mathrm{N} / 5^{\circ} \mathrm{E}\right.$, right). Only simulations for $\mathrm{SZA}<90^{\circ}$ are plotted.

tude locations. Figure 5 also shows difference between GMI tropospheric $\mathrm{NO}_{2} T_{\text {eff }}$ and GMI surface temperature $(10 \mathrm{~m})$. Average difference (tropospheric $T_{\text {eff }}-T$ at $10 \mathrm{~m}$ ) in summer is $-5 \pm 2.5 \mathrm{~K}$ which corresponds roughly to adiabatic lapse rate of $9.8 \mathrm{~K} \mathrm{~km}^{-1}(H \sim 0.5 \mathrm{~km})$. Average annual differences in 2011 for the northwestern USA and northwestern Europe are $-3.8 \pm 2.9 \mathrm{~K}$ and $-3.7 \pm 2.1 \mathrm{~K}$, respectively. Due to large GMI cell size and $\mathrm{NO}_{2}$ emission spatial averaging, the actual tropospheric $\mathrm{NO}_{2}$ profile temperature is probably closer to the surface temperature than GMI-estimated. We conclude that $T_{\text {vertical }}^{\mathrm{TRO}}$ can be approximated by a temperature range from $T$ at the surface $\left(T_{0} \mathrm{~km}\right)$ to $\left(T_{0} \mathrm{~km}-3 \mathrm{~K}\right)$.
Figure 5 shows the GMI CTM estimated total and stratospheric $\mathrm{NO}_{2}$ profile $T_{\text {eff }}$ for these two sites, where the offset between total and stratospheric $T_{\text {eff }}$ is due to the tropospheric contribution. Moderately polluted northwestern Europe has an offset of $\sim 40 \mathrm{~K}$, while clean continental northwestern USA has an offset of $<20 \mathrm{~K}$.

Table 1 summarizes steps to calculate total VCD at $T$ and separate it into $\mathrm{VCD}^{\mathrm{TROP}}$ and $\mathrm{VCD}^{\mathrm{STRAT}}$ using assumptions about $T^{\mathrm{TROP}}$ and $T^{\mathrm{STRAT}}$. 


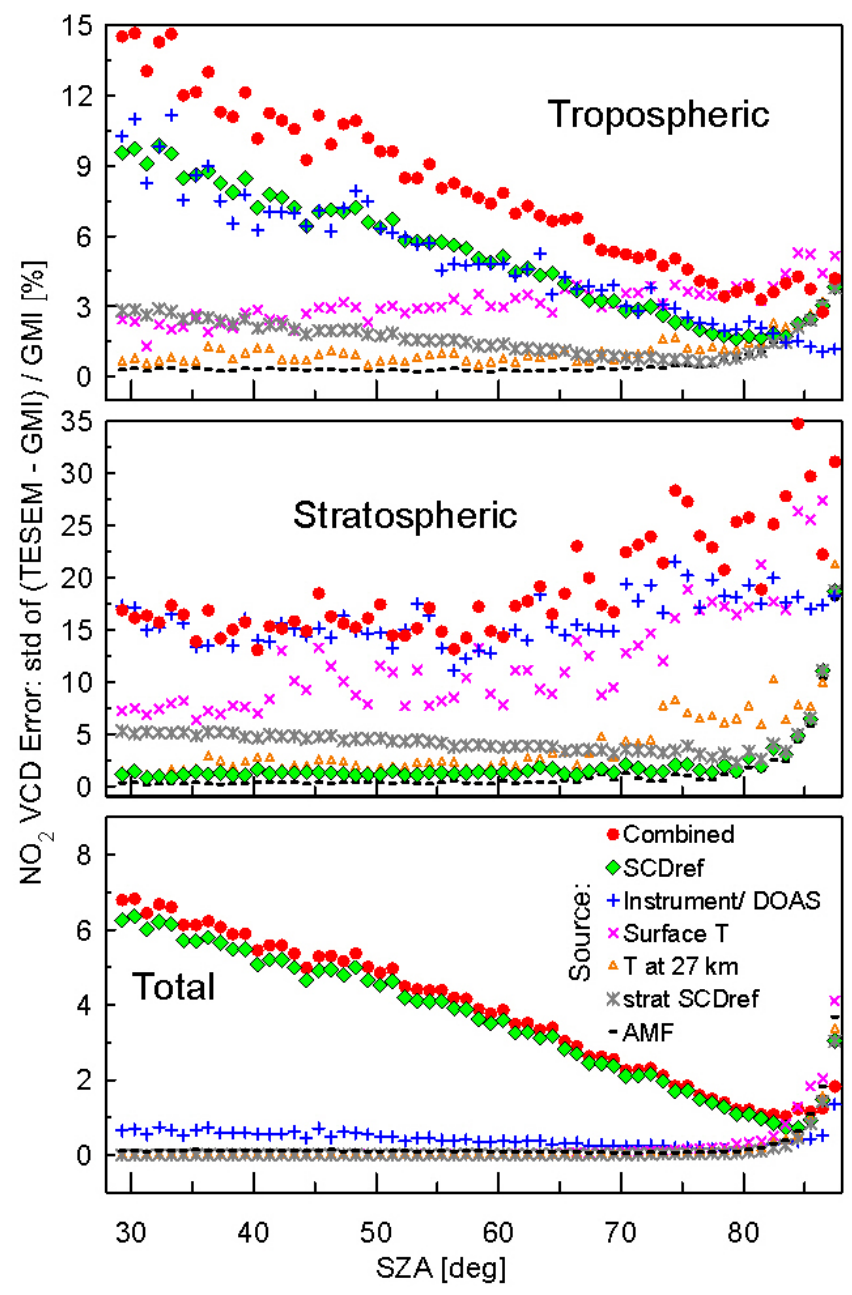

Figure 6. Error estimation for TESEM tropospheric, stratospheric, and total vertical columns using GMI $\mathrm{NO}_{2} \mathrm{VMR}$ and temperature/pressure profiles over northwestern Europe $\left(52^{\circ} \mathrm{N} / 5^{\circ} \mathrm{E}\right)$ for the year 2011 (SZA $<90^{\circ}, 4466$ data points; see text for details) and MFDOAS errors in DOAS fitting of $\mathrm{NO}_{2}$.

\section{MFDOAS instrument description and DOAS analysis setup}

\subsection{MFDOAS instrument description}

MFDOAS is a grating spectrometer system with a spectral resolution of $0.83 \mathrm{~nm}$ and oversampling at 7.8 pixels per full width at half maximum (FWHM) covering the $282-498 \mathrm{~nm}$ wavelength range. It is capable of directsun and MAX-DOAS observations. A scientific-grade CCD (Princeton Instruments: PIXIS $2 \mathrm{kBUV}, 512 \times 2048$ ) is coupled with a $300 \mathrm{~mm}$ focal length single-path Czerny-Turner spectrograph (upgraded based on SpectraPro 2356), with a 400 groove $\mathrm{mm}^{-1}$ grating. The CCD is thermoelectrically cooled to $-70^{\circ} \mathrm{C}$ to reduce dark current noise. Photons in direct-sun and scattered-light modes are collected by a telescope through a $74 \mathrm{~cm}$ long sky collimator with a quartz win- dow. A series of black anodized baffles inside the collimator help reduce scattering and entry of out-of-field-of-view light into the spectrograph. Direct-sun light is guided into the $8 \mathrm{~cm}$ diameter Spectralon integrating sphere by three folding mirrors. The integrating sphere assures uniform illumination of the spectrometer optics and minimizes the effect of pointing inaccuracy. Depending on the operational mode (direct sun or sky view), the integrating sphere moves in and out of the spectrometer field of view (FOV). Before entering the spectrometer, light passes through two filter wheels that contain UV transmitting filters (Hoya U340) for removing visible light, depolarizers (Halbo Optics WDQ25), a plug to block all light for dark current measurements, a polarizer, and a UV-absorbing filter (Schott WG345).

The light input optics and spectrometer-CCD detection system is enclosed in a temperature-controlled box $(20 \pm$ $1{ }^{\circ} \mathrm{C}$ ) which is placed on a Kipp and Zonen 2AP G sun tracker/positioner. After an initial instrument alignment, the Sun's position is determined using a solar ephemeris calculation. The pointing precision and accuracy of the instrument FOV are 0.05 and $0.1^{\circ}$, respectively. Wavelength calibration was determined by measuring emission lines from different calibration $(\mathrm{HgNe}, \mathrm{Ne}, \mathrm{Kr}, \mathrm{Xe})$ and hollow-cathode lamps $(\mathrm{Ag}(\mathrm{Ne}), \mathrm{Pt}(\mathrm{A}), \mathrm{Cr})$ as well as from solar Fraunhofer lines.

\subsection{Data description and DOAS analysis setup}

The TESEM to derive slant profile effective temperature with the subsequent separation of stratospheric and tropospheric columns from DOAS measurements is applied to MFDOAS DS data collected during the months of May-August. Here we present analysis of data collected at four northern midlatitude locations: two with moderate to high anthropogenic pollution and two with low pollution rates.

JPL-TMF is located in California, USA, and is characterized by low $\mathrm{NO}_{2}$ pollution levels due to the high altitude $(\sim 2.3 \mathrm{~km})$. On most days heavily polluted Los Angeles Basin air is confined below $2.3 \mathrm{~km}$. During afternoon hours, however, the PBL height approaches the JPL-TMF's altitude and larger pollution amounts are present (Wang et al., 2010). Pullman, WA (home to Washington State University, WSU), is located in a rural, wheat-growing part of eastern Washington State. The main source of $\mathrm{NO}_{\mathrm{x}}$ pollution is vehicular emissions produced by the $\sim 30000$ population, with an $\sim 20000$ student body. In this work we present data collected during summer months (July, August 2011), when most students were not present at Pullman WSU campus. As a result, the $\mathrm{NO}_{2}$ levels are very close to continental background. The Cabauw Experimental Site for Atmospheric Research, a rural site in the heart of the Netherlands, is characterized by relatively large regional $\mathrm{NO}_{2}$ pollution. Observations during the Cabauw Intercomparison campaign for Nitrogen Dioxide Measuring Instruments (CINDI, June-July 2009; Piters et al., 2012) are presented here. NASA Goddard Space Flight Center (NASA/GSFC) is located in Greenbelt, MD, which is 
part of the Baltimore-Washington metropolitan area. This is an urban site with large $\mathrm{NO}_{\mathrm{x}}$ emissions. A summary of the measurement site description including the source of temperature profiles, campaign-average temperatures at $27 \mathrm{~km}$, and surface temperatures can be found in Table 2 .

Depending on the goals of the individual field campaigns, MFDOAS operated in different modes. In general, DS and MAX-DOAS measurements were taken in sequence. The interval between DS measurements depended on the number of MAX-DOAS elevation angles and directions. The JPL-TMF campaign was devoted to intercomparison between instruments in DS mode. As a result, high-temporalresolution data are available (every minute). Measurements over the WSU/Pullman and Cabauw sites had a large emphasis on MAX-DOAS measurements, and as a result DS data are available only every $15-20 \mathrm{~min}$. Observations over NASA/GSFC again had a large emphasis on DS measurements, with DS visible $\mathrm{NO}_{2}$ data available every $5 \mathrm{~min}$.

Due to a difference in design (smaller telescope), the signal-to-noise ratio in data collected over the JPL-TMF site was smaller than in measurements at other sites. The least favorable DS measurement conditions were observed at Cabauw because of the measurement schedule and meteorological conditions. DS reference spectra were measured around local noon on 7 July 2007 for JPL-TMF, 4 July 2009 for Cabauw, 7 August 2011 for WSU/Pullman, and 3 May 2013 for NASA/GSFC. To reduce noise propagation from the reference spectrum into DOAS analysis results, several spectra were averaged to create a single reference spectrum.

Table 3 lists all DOAS fitting parameters used to retrieve $\mathrm{NO}_{2} \Delta$ SCD from MFDOAS DS measurements. DOAS fitting was done using QDOAS software (Danckaert et al., 2012). In addition to deriving $T$ from the visible measurements, we also conducted a "traditional" DOAS analysis using $\mathrm{NO}_{2}$ cross section at a single temperature $(238 \mathrm{~K}$ for the JPL-TMF and WSU/Pullman sites, and $270 \mathrm{~K}$ for the Cabauw and NASA/GSFC sites), and $\mathrm{NO}_{2}$ cross sections at two temperatures ( 220 and $298 \mathrm{~K}$ ).

$T$ was derived using the Vandaele et al. (2003) linear regression model at $T_{0}=220 \mathrm{~K}$. The stratospheric $\mathrm{NO}_{2}$ profile effective temperature was taken from atmospheric soundings or ozonesondes at $27 \mathrm{~km}$. Tropospheric temperature was approximated as surface temperature.

\section{TESEM error estimation and limitations}

TESEM uncertainty is approximated using GMI $\mathrm{NO}_{2}$ profiles over a polluted location (northwestern Europe). Error estimation of the total, tropospheric, and stratospheric $\mathrm{NO}_{2}$ columns is done by adding instrumental/DOAS fitting noise to the GMI yearly data and reporting the standard deviation of the percent difference between GMI initial data and
TESEM results as a function of SZA for different uncertainty sources. The main sources of error in TESEM are as follows:

1. Instrumental and DOAS fitting errors. Fitting errors of $\triangle \mathrm{SCD}$ and $\triangle \mathrm{SCD} T_{\alpha}$ are linearly related to the root mean square (rms) of the DOAS fitting residual OD. The residual OD can be considered as a sum of all instrumental and DOAS fitting errors (assuming all absorbers are accounted for). The MFDOAS error in $\triangle \mathrm{SCD}$ is $2.045 \times 10^{14}$ molecules $\mathrm{cm}^{-2}$ and $\triangle \mathrm{SCD} T_{\alpha}$ is $7.024 \times 10^{16}$ molecules $T \mathrm{~cm}^{-2}$ per $10^{-4}$ residual OD rms. We analyzed spectra measured over GSFC from November 2012 through October 2013 using a single Fraunhofer reference spectrum collected on 3 May 2013 to evaluate dependence of residual OD rms on SZA. For MFDOAS winter measurements over GSFC analyzed with the reference Fraunhofer spectrum collected in summer (worst-case scenario), residual OD rms vs. SZA can be described by a power function: $1.5098 \times$ $10^{-4}+1.6485 \times 10^{20} \cdot \mathrm{SZA}^{8.0809}$, with Gaussian distribution at each SZA (width $\left.=1.4994 \cdot 10^{-5}\right)$. We added Gaussian distributed residual OD ( $f$ (wavelength) and $f(\mathrm{SZA}))$ to $\ln \left(I_{\mathrm{REF}} / I\right)$ and carried out QDOAS fitting to simulate $\triangle \mathrm{SCD}$ and $\triangle \mathrm{SCD} T_{\alpha}$ measurements from GMI data in the presence of MFDOAS noise.

2. AMF errors. At $\mathrm{SZA}<75^{\circ} \mathrm{AMF}$ errors are very small: $<1 \%$. For a larger SZA, the AMF depends on the profile and precise knowledge of the $\mathrm{NO}_{2} H_{\text {eff. }}$ At SZA > $88^{\circ}$, refraction introduces AMF wavelength dependence and is not considered here.

3. $T^{\text {STRAT }}$ and $T^{\text {TROP }}$ errors. The effect of this source depends on the pollution level. Uncertainties in $T^{\text {STRAT }}$ can significantly (up to $35 \%$ ) contribute to VCD ${ }^{\text {STRAT }}$ over low-pollution locations. $T^{\mathrm{STRAT}}$ and $T^{\mathrm{TROP}}$ errors are peaking during winter at midlatitude sites.

4. Errors of stratospheric and total SCD in the reference spectrum. The estimated errors in $\mathrm{SCD}^{\mathrm{REF}}$ from MLE and in $\mathrm{SCD}_{\mathrm{REF}}^{\mathrm{STRAT}}$ from the Langley plot are on the order of $8-10 \%$.

5. Uncertainty in absolute $\mathrm{NO}_{2}$ cross sections is estimated to be $3 \%$.

Figure 6 shows relative errors calculated for moderately polluted northwestern Europe ( $\left.52^{\circ} \mathrm{N} / 5^{\circ} \mathrm{E}\right)$ using GMI simulation for year 2011 as a function of SZA. Tropospheric VCD combined errors show SZA dependence with maximum values of $15 \%$ and $5 \%$ at high- and low-sun positions, respectively. Stratospheric VCD errors tend to be larger overall $(20-35 \%)$ and increase as a function of SZA. The total $\mathrm{NO}_{2}$ $\mathrm{VCD}$ error is mainly driven by the uncertainty in $\mathrm{SCD}^{\mathrm{REF}}$ and ranges between 7 and $3 \%$, with a maximum at small SZA. A similar analysis on the GMI data over the northwestern "clean" USA (not shown) revealed significantly larger 
Table 2. MFDOAS measurement sites, observation periods and estimated stratospheric and tropospheric vertical $\mathrm{NO}_{2}$ profile-weighted temperatures.

\begin{tabular}{|c|c|c|c|c|c|c|}
\hline $\begin{array}{l}\text { Site name and } \\
\text { location }\end{array}$ & $\begin{array}{l}\text { Elev. } \\
{[\mathrm{m}]}\end{array}$ & Dates & $\begin{array}{l}\text { Source of temperature at } \\
27 \mathrm{~km}^{\mathrm{a}}\end{array}$ & $\begin{array}{l}\text { Mean } T \text { at } \\
27 \mathrm{~km}[\mathrm{~K}]\end{array}$ & $\begin{array}{l}\text { Mean } T \text { at } \\
\text { surface }[\mathrm{K}]\end{array}$ & $\begin{array}{l}\text { Pollution } \\
\text { level }\end{array}$ \\
\hline $\begin{array}{l}\text { Table Mountain - } \\
\text { JPL facility, CA } \\
\text { Lat: } 34.38^{\circ} \mathrm{N} \\
\text { Lon: } 117.68^{\circ} \mathrm{W}\end{array}$ & 2285 & 2-12 Jul 2007 & Ozone sondes & $225.84 \pm 1.58$ & $298.20 \pm 3.04$ & low \\
\hline $\begin{array}{l}\text { WSU, } \\
\text { Pullman, } \mathrm{WA}^{\mathrm{b}} \\
\text { Lat: } 46.7325^{\circ} \mathrm{N} \\
\text { Lon: } 117.169^{\circ} \mathrm{W}\end{array}$ & 764 & Jul, Aug 2011 & $\begin{array}{l}\text { Atm. soundings from } \\
\text { Spokane, WA } \\
\left(47.68^{\circ} \mathrm{N}, 117.63^{\circ} \mathrm{W}\right)\end{array}$ & $227.29 \pm 1.62$ & $295.85 \pm 4.33$ & low \\
\hline $\begin{array}{l}\text { Cabauw, } \\
\text { the Netherlands } \\
\text { Lat: } 51.971^{\circ} \mathrm{N} \\
\text { Lon: } 4.927^{\circ} \mathrm{E}\end{array}$ & $\sim 0$ & $\begin{array}{l}15 \\
\text { 4 Jul } 2009\end{array}$ & $\begin{array}{l}\text { Atm. soundings from } \\
\text { DeBilt, the Netherlands } \\
\left(52.10^{\circ} \mathrm{N}, 5.18^{\circ} \mathrm{E}\right)\end{array}$ & $228.18 \pm 1.65$ & $296.41 \pm 2.90$ & moderate-high \\
\hline $\begin{array}{l}\text { NASA/GSFC } \\
\text { Greenbelt, } \mathrm{MD}^{\mathrm{b}} \\
\text { Lat: } 38.993^{\circ} \mathrm{N} \\
\text { Lon: } 76.839^{\circ} \mathrm{W}\end{array}$ & $\sim 60$ & May 2013 & $\begin{array}{l}\text { Atm. soundings from } \\
\text { Sterling, VA } \\
\left(38.98^{\circ} \mathrm{N}, 77.46^{\circ} \mathrm{W}\right)\end{array}$ & $223.78 \pm 2.13$ & $293.37 \pm 6.19$ & moderate-high \\
\hline
\end{tabular}

Table 3. DOAS fitting parameters used to analyze $\mathrm{NO}_{2}$ visible direct-sun data.

\begin{tabular}{lll}
\hline $\mathrm{NO}_{2}$ visible fitting wavelength window: $435-485 \mathrm{~nm}$ \\
Reference spectra: local noon \\
Polynomial order: 4 \\
Stray light correction: slope \\
\hline Species & Abs. cross section temperature [K] & Reference \\
\hline $\mathrm{O}_{3}$ & 223,243 & Malicet et al. (1995) \\
\hline $\mathrm{NO}_{2}$ & (A) 298 and $220 ;$ & Vandaele et al. (1998) \\
& (B) $270 ;$ & \\
& (C) $238 ;$ & \\
\hline $\mathrm{O}_{2} \mathrm{O}_{2}$ & (D) Derived $T$ : linear model & $\begin{array}{l}\text { Hermans et al., 2003, unpublished re- } \\
\text { sults } \\
\text { http://spectrolab.aeronomie.be/o2.htm }\end{array}$ \\
\hline $\mathrm{H}_{2} \mathrm{O}$ & 296 & Rothman et al. (2010) \\
\hline
\end{tabular}

errors in stratospheric VCD in winter (up to $120 \%$ ) at small SZA decreasing to $15-20 \%$ at SZA $>80^{\circ}$, mainly caused by the uncertainty in $T^{\mathrm{STRAT}} / T^{\mathrm{TROP}}$. Tropospheric VCD combined errors are on the order of 15-20\% and show very small dependence on SZA.

The errors, in general, are smaller for summer months compared to winter at these midlatitude locations due to more accurate estimation of $T^{\text {STRAT }}$ and $T^{\mathrm{TROP}}$, larger stratospheric VCD and lower instrumental/DOAS fitting errors. The main limitations of TESEM for separation of tropospheric and stratospheric column contributions are (1) the instrumental overall noise expressed as DOAS fitting OD residuals, (2) the availability of sufficient measurements at $\mathrm{SZA}<75^{\circ}$ to derive $\mathrm{SCD}{ }^{\mathrm{REF}}$ and $T^{\mathrm{REF}}$, (3) the small difference between total and stratospheric $\mathrm{NO}_{2}$ columns and their corresponding effective temperatures, and (4) the accuracy in estimation of tropospheric and stratospheric effective temperatures. Application of TESEM to cold winter measurements should be done with caution since temperature inversions increase $T^{\mathrm{TROP}}$ compared to $T$ at the surface, and $T^{\text {START }}$ is not accurately represented by $T$ at $27 \mathrm{~km}$. 

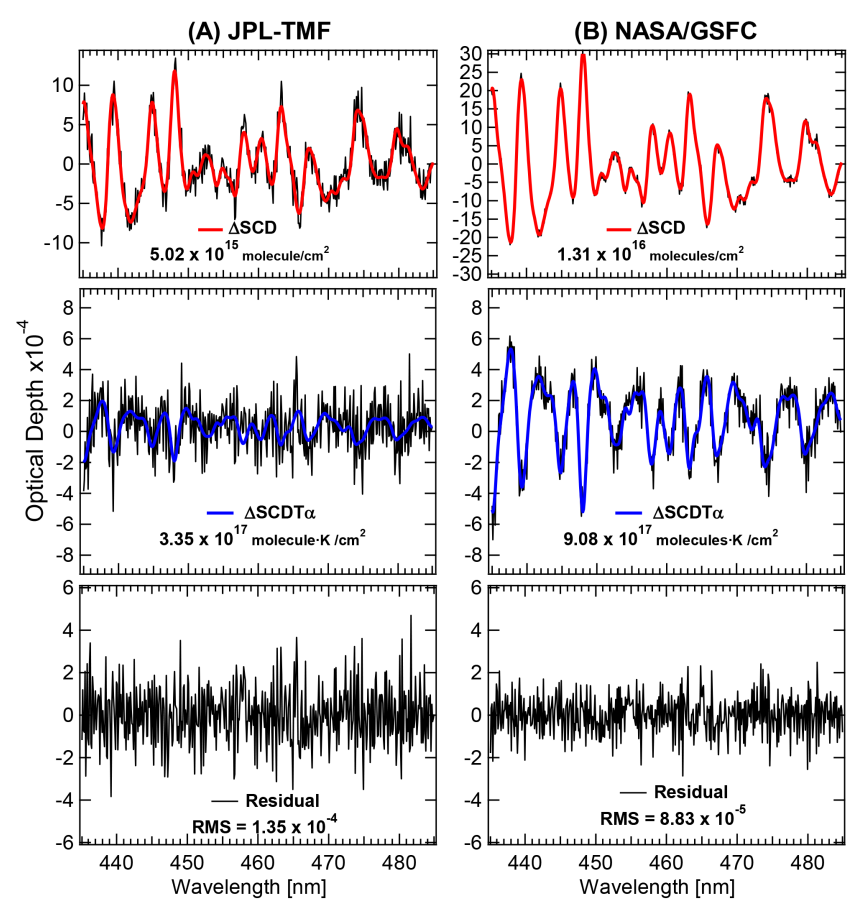

Figure 7. Example of DOAS spectral fit of retrieved $\mathrm{NO}_{2} \Delta \mathrm{SCD}$ at $T$ and $\triangle \mathrm{SCDT} \alpha$ from MFDOAS direct-sun irradiance measurements $\left(435-485 \mathrm{~nm}, T_{0}=220 \mathrm{~K}\right)$ over (a) JPL-TMF, California ( 14:56 PST, 12 July 2007; reference taken at noon on 7 July 2007), and (b) NASA/GSFC (09:12 EST, 17 May 2013; reference taken at noon on 3 May 2013).

\section{Results}

The main goal of this section is to demonstrate that TESEM accurately calculates total $\mathrm{NO}_{2} \Delta \mathrm{SCD}$ at profile $T$ and provides a reasonable estimation of stratospheric and tropospheric columns based on retrieved $\mathrm{NO}_{2}$ slant profile effective temperature from DS DOAS observations. It also compares DS DOAS retrievals from TESEM and traditional DOAS fitting methods.

\section{1 $\mathrm{NO}_{2}$ profile $T$, total, stratospheric, and tropospheric $\mathrm{NO}_{2}$ VCD}

Since the quality of the DOAS spectral fit greatly impacts the success of TESEM, we first show the OD of gaseous absorbers fitted by QDOAS software for two sites: JPL-TMF and NASA/GSFC. JPL-TMF is a challenging site due to low $\mathrm{NO}_{2}$ total and tropospheric columns. NASA/GSFC, on the other hand, is characterized by large $\mathrm{NO}_{2}$ tropospheric columns. Figure 7a shows a QDOAS fit of DS data collected over JPL-TMF at $\sim 14: 56$ PST on 12 July 2007 in the visible $(435-485 \mathrm{~nm})$, when total $\mathrm{NO}_{2} \Delta \mathrm{SCD}$ is $\sim 5 \times$ $10^{15}$ molecules $\mathrm{cm}^{-2}$, with less than $50 \%$ of it tropospheric. Figure $7 \mathrm{~b}$ shows a similar plot for the same AMF (1.34, 09:12 EST on 17 May 2013) over NASA/GSFC where the to-

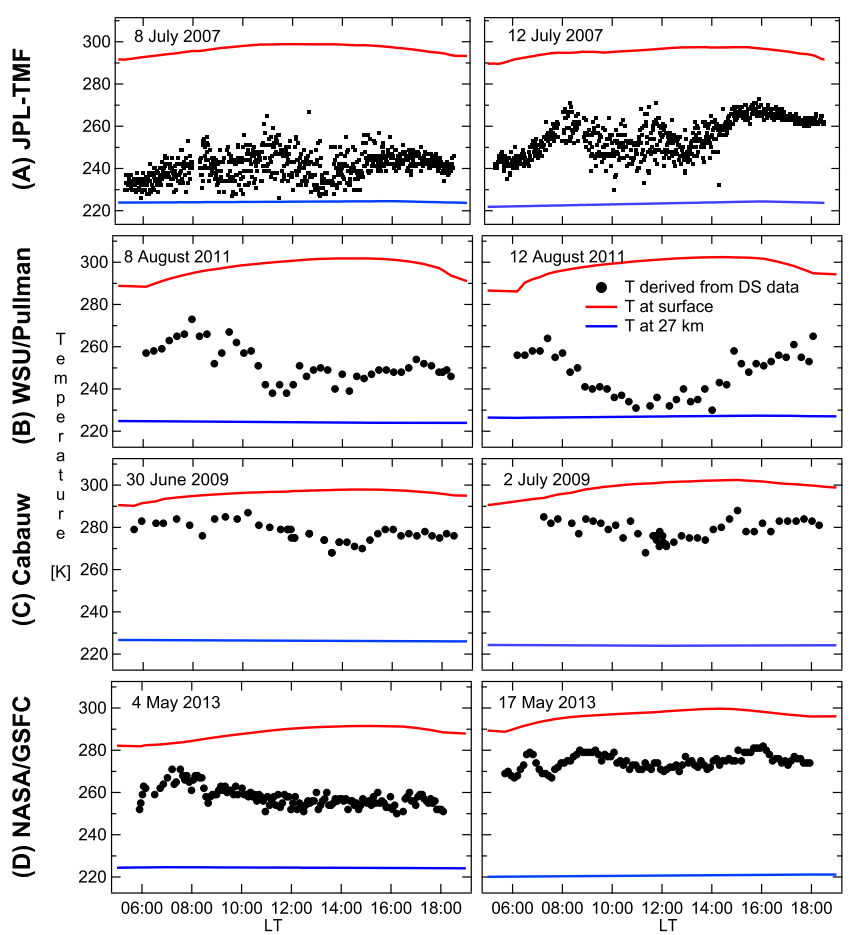

Figure 8. $\mathrm{NO}_{2}$ slant-profile-weighted temperatures derived from MFDOAS direct-sun measurements (435-485 nm) over two "clean" and two "polluted" sites: (a) JPL-TMF, CA (8 and 12 July 2007); (b) WSU Pullman, WA (8 and 12 August 2001); (c) Cabauw, the Netherlands (30 June and 4 July 2009); and (d) NASA/GSFC Greenbelt, MD (4 and 17 May 2013).

tal $\mathrm{NO}_{2} \Delta \mathrm{SCD}$ is $\sim 1.3 \times 10^{16}$ molecules $\mathrm{cm}^{-2}$, with $\sim 80 \%$ of it tropospheric. Residual OD rms at JPL-TMF is somewhat larger $\left(1.35 \times 10^{-4}\right)$ than at NASA/GSFC $\left(8.85 \times 10^{-5}\right)$ due to design improvement in MFDOAS. Figure 7 shows that DOAS analysis can separate temperature-dependent $\mathrm{NO}_{2}$ absorption at residual OD rms, , which is characteristic to the MFDOAS instrument.

Figure 8 shows examples of derived total $\mathrm{NO}_{2}$ profile $T$ from direct-sun MFDOAS measurements with timecoincident surface temperatures and interpolated temperatures at $27 \mathrm{~km}$ over four sites. We selected one day with low $\mathrm{NO}_{2}$ loading and one day with high $\mathrm{NO}_{2}$ loading from each site. The difference in estimated $T$ between measurements at times with high and low emissions can be as high as $20 \mathrm{~K}$. Table 4 lists mean effective $\mathrm{NO}_{2}$ profile temperatures retrieved at each site during selected periods. Temperature differences between estimated $\mathrm{NO}_{2}$ total column $T$ and stratospheric $T$ were $17 \pm 12 \mathrm{~K}$ over JPL-TMF, $27 \pm 9 \mathrm{~K}$ over WSU/Pullman, $48 \pm 7 \mathrm{~K}$ over Cabauw, and $39 \pm 10 \mathrm{~K}$ over NASA/GSFC.

Total $\mathrm{NO}_{2} \Delta \mathrm{SCD}$ calculated with the DOAS fitting algorithm (QDOAS) as a function of the direct-sun AMF over JPL-TMF (July 2007), WSU/Pullman (July, August 2011), and NASA/GSFC (May 2013) are shown in Fig. 9. The figure also includes the resulting stratospheric and tropospheric 
Table 4. Table 4 MFDOAS measurement sites, observation periods and estimated total, stratospheric, and tropospheric $\mathrm{NO}_{2}$ effective temperatures.

\begin{tabular}{llllll}
\hline Site name & Dates & $\begin{array}{l}\text { Est. mean } \\
\mathrm{NO}_{2} T[\mathrm{~K}]\end{array}$ & $\begin{array}{l}\text { Measured mean } \\
\mathrm{NO}_{2} T[\mathrm{~K}]\end{array}$ & $\begin{array}{l}\mathrm{NO}_{2} \\
\left(T-T_{27} \mathrm{~km}\right)[\mathrm{K}]\end{array}$ & $\begin{array}{l}\text { Slope } / R^{2} \\
\Delta \mathrm{SCD}_{T \text { fixed }} \mathrm{vs.} \Delta \mathrm{SCD} \text { TESEM }\end{array}$ \\
\hline $\begin{array}{l}\text { TMF - JPL, CA } \\
\left(34.38^{\circ} \mathrm{N}, 117.68^{\circ} \mathrm{W}\right)\end{array}$ & 2-12 Jul 2007 & 238 & $243 \pm 12$ & $17 \pm 12$ & $0.941 / 0.998$ \\
\hline $\begin{array}{l}\text { WSU, Pullman, WA } \\
\left(46.73^{\circ} \mathrm{N}, 117.17^{\circ} \mathrm{W}\right)\end{array}$ & Jul, Aug 2011 & 240 & $254 \pm 9$ & $27 \pm 9$ & $0.963 / 0.998$ \\
\hline $\begin{array}{l}\text { Cabauw, the Netherlands } \\
\left(51.97^{\circ} \mathrm{N}, 4.93^{\circ} \mathrm{E}\right)\end{array}$ & 15 Jun-4 Jul 2009 & 270 & $276 \pm 7$ & $48 \pm 7$ & $0.996 / 0.998$ \\
\hline $\begin{array}{l}\text { NASA/GSFC, Greenbelt, MD } \\
\left(38.99^{\circ} \mathrm{N}, 76.84^{\circ} \mathrm{W}\right)\end{array}$ & May 2013 & 270 & $263 \pm 10$ & $39 \pm 10$ & $1.038 / 0.997$ \\
\hline
\end{tabular}

$\triangle \mathrm{SCD}$ based on the derived effective $\mathrm{NO}_{2}$ profile temperatures. There is a clear separation of the total $\mathrm{NO}_{2} \Delta \mathrm{SCD}$ into stratospheric and tropospheric columns. It is especially pronounced in JPL-TMF and WSU/Pullman data, where morning and afternoon stratospheric $\mathrm{NO}_{2} \Delta \mathrm{SCD}$ have different slopes due to different photolysis rates. More variability in stratospheric $\mathrm{NO}_{2}$ columns over NASA/GSFC can be partially explained by more variability in solar actinic flux in May 2013 compared to measurement days in July 2007 (JPLTMF) and in July-August 2011 (WSU/Pullman) (daily solar flux data are available from ftp://ftp.geolab.nrcan.gc.ca/data/ solar_flux/daily_flux_values/). However it cannot fully explain large changes in $T_{27} \mathrm{~km}(6-8 \mathrm{~K})$ over NASA/GSFC in May 2013 from day to day compared to no more than $3 \mathrm{~K}$ over the two other sites.

Under low pollution and small changes in $\triangle$ SCD, TESEM sometimes overestimates tropospheric column fractions due to high sensitivity to assumed stratospheric and tropospheric temperatures, as well as higher errors in $\triangle \mathrm{SCD}$ and $\triangle \mathrm{SCD} T_{\alpha}$. The resulting errors in stratospheric VCD are $\leq 1 \times 10^{15}$ molecules $\mathrm{cm}^{-2}$. In this study we apply running average smoothing of the derived stratospheric vertical columns by $4 \mathrm{~h}$ periods, and then use these new stratospheric columns to recalculate tropospheric columns.

Figure 10 shows total, stratospheric, and tropospheric $\mathrm{NO}_{2}$ VCD over four sites derived from MFDOAS DS $\mathrm{NO}_{2} T$ shown in Fig. 8. Campaignaverage total $\mathrm{NO}_{2} \quad \mathrm{VCD}$ over JPL-TMF was $(3.9 \pm 1.1) \times 10^{15}$ molecules $\mathrm{cm}^{-2}$, with about $30 \%$ of it tropospheric $\left((1.2 \pm 0.9) \times 10^{15}\right.$ molecules $\left.\mathrm{cm}^{-2}\right)$. Similar on average VCD were observed over WSU/Pullman site $\left((4.0 \pm 0.8) \times 10^{15}\right.$ total, $(1.0 \pm 0.7) \times 10^{15}$ molecules $\mathrm{cm}^{-2}$ tropospheric). Cabauw air was "polluted"on almost all days when DS measurements were available, and an average total column was $(1.3 \pm 0.3) \times 10^{16}$, with $(9.5 \pm 3.2) \times 10^{15}$ tropospheric pollution. NASA/GSFC site had relatively clean and also highly polluted days depending on the day of week and wind direction. An average total observed column was $(8.8 \pm 3.5) \times 10^{15}$ and tropospheric $(5.6 \pm 3.5) \times 10^{15}$ molecules $\mathrm{cm}^{-2}$.
Derived stratospheric VCD have a reasonable photolytic rate "slope" at all sites. The agreement between the GMI CTM stratospheric VCD over WSU/Pullman site is within $6 \%$ with a linear correlation $R^{2}=0.92$. To demonstrate validity of TESEM to DS measurements, we compare total and tropospheric columns with time-coincident measurements. MFDOAS direct-sun total $\mathrm{NO}_{2}$ columns were validated using a high-resolution $(0.001 \mathrm{~nm})$ Fourier transform ultraviolet spectrometer (FTUVS) over JPL-TMF (Wang et al., 2010) that retrieves absolute columns and does not require Langleytype calibration. The total VCD derived by the MFDOAS and FTUVS instruments agreed within $(1.5 \pm 4.1) \%$. We applied a modified version of TESEM to MAX-DOAS $\left(30^{\circ} \mathrm{el}-\right.$ evation angle) data to derive tropospheric SCD. VCD were calculated using a geometrical approach where tropospheric $\mathrm{AMF} \approx 2$ at $\mathrm{SZA}<75^{\circ}$ (range of MAX-DOAS applicability). The tropospheric columns agree within $30 \%$. An extensive discussion of stratospheric columns derived from zenith sky and DS, as well as tropospheric columns from multi-axis, DS, and zenith sky DOAS measurements over Cabauw during CINDI 2009, is presented in Spinei et al. (2014).

The supplementary material contains stratospheric and tropospheric $\mathrm{NO}_{2} \mathrm{VCD}$ results for fall/winter over GSFC/NASA and fall over WSU/Pullman. In general, winter measurements over mid-latitudes tend to underestimate stratospheric $\mathrm{NO}_{2}$ VCD due to higher uncertainty in $T^{\mathrm{STRAT}}$ and $T^{\text {TROP }}$. The method completely fails to separate total columns into stratospheric and tropospheric components during temperature inversion events over polluted locations when the retrieved $T$ is larger than the surface temperature.

\subsection{Comparison of $\mathrm{NO}_{2} \Delta \mathrm{SCD}$ derived from $T$ fit and "traditional" fittings}

The most common "standard" approach is to estimate $\mathrm{NO}_{2}$ $T$ based on modeling results or in situ measurements and apply this $T$ along with the assumed $\mathrm{NO}_{2}$ effective height to all of the measurements (Herman et al., 2009). GMI estimated $\mathrm{NO}_{2}$ profile $T$ is $238 \mathrm{~K}$ over the JPL-TMF site, $\sim 240 \mathrm{~K}$ over WSU/Pullman, and $270 \mathrm{~K}$ over NASA/GSFC and Cabauw 

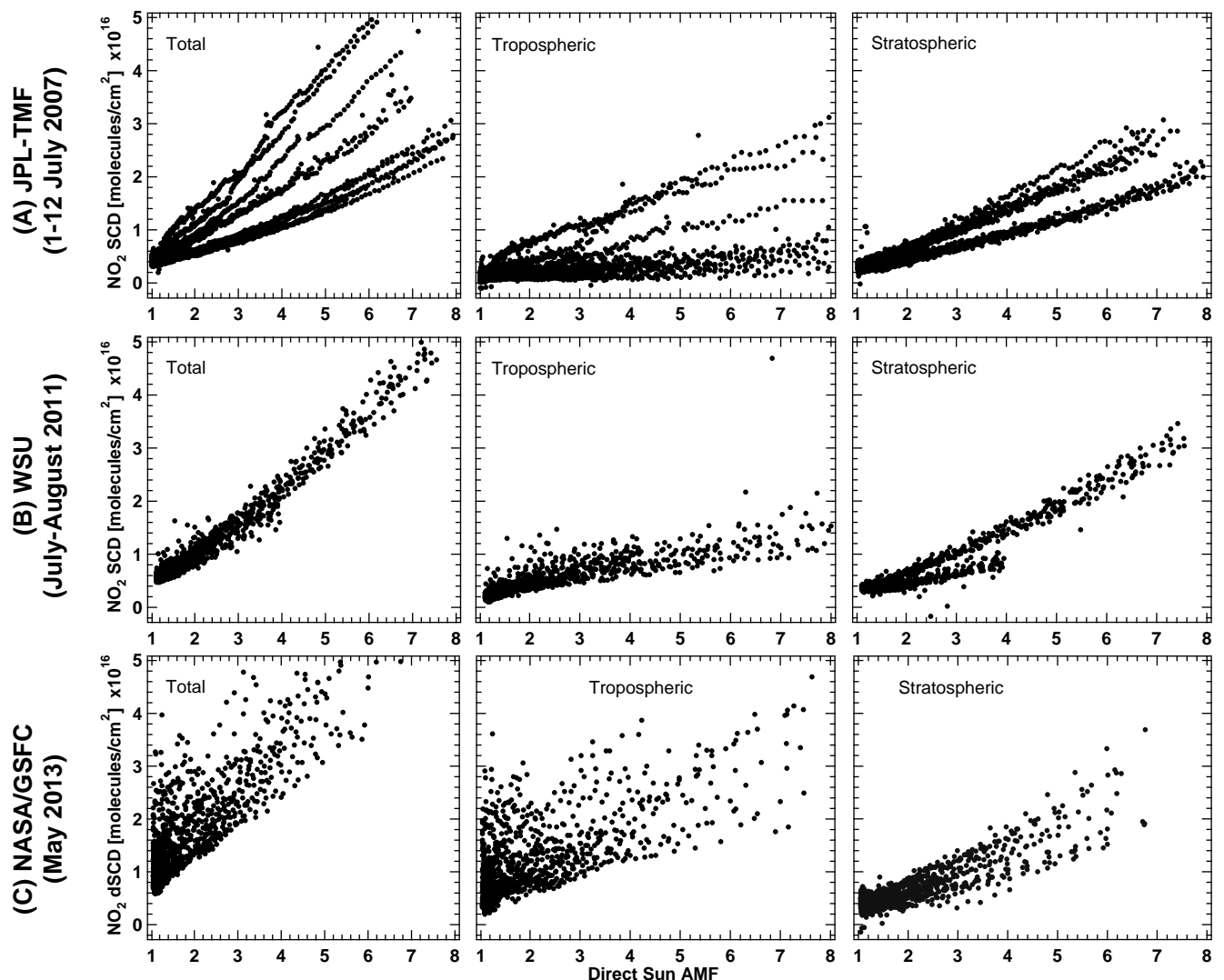

Figure 9. $\mathrm{NO}_{2}$ total, stratospheric, and tropospheric SCD derived from MFDOAS direct-sun measurements (435-485 nm) over (a) JPL-TMF, California (2-12 July 2007); (b) WSU (July-August 2011); and (c) NASA/GSFC (1-31 May 2013). No smoothing of stratospheric columns is shown.

sites. [CE]This sentence is difficult to follow. Please check whether correct; if not, please reformulate so that it reflects what is meant. - the sentence was rearranged. In this study we linearly interpolate Vandaele et al. (2003) $\mathrm{NO}_{2}$ cross sections at 220 and $298 \mathrm{~K}$ to the desired temperatures. Fitting a constant temperature cross section results in biases that are pollution and temperature dependent. For polluted regions, during high $\mathrm{NO}_{2}$ emission rates, the fixed-temperature DOAS fitting underestimates $\triangle \mathrm{SCD}$ relative to TESEM by up to $5-10 \%$, while for the times with lower emission rates, the fixed-temperature method overestimates $\triangle \mathrm{SCD}$ relative to TESEM by about $5-15 \%$. On average, the agreement is very good (within 1-6\%, Table 4) during the summer months evaluated in this study. For sites with relatively constant $\mathrm{NO}_{2}$ emission rates or background $\mathrm{NO}_{2}$, the fixed-temperature method is fairly accurate, presuming that the effective temperature is estimated correctly. Since a single $T$ is used to analyze data independent of season, systematic seasonal errors are expected even for such sites.

The second "standard" approach consists of simultaneous fitting of $\mathrm{NO}_{2} \sigma$ at assumed stratospheric $(220 \mathrm{~K})$ and tropospheric $(298 \mathrm{~K})$ temperatures. Two variations of this method exist: independent cross section fitting and "orthog- onalized fitting". Since TESEM uses a $\sigma\left(\mathrm{NO}_{2}\right)$ linear model derived from $\sigma_{298 \mathrm{~K}}$ and $\sigma_{220 \mathrm{~K}}$, total $\Delta \mathrm{SCD}\left(\Delta \mathrm{SCD}^{220 \mathrm{~K}}+\right.$ $\triangle \mathrm{SCD}^{298 \mathrm{~K}}$ ) from the independent fitting of two cross sections is less than $1 \%$ different than $\triangle \mathrm{SCD}$ from TESEM.

Orthogonalized fitting is typically done as an attempt to remove cross correlation between $\mathrm{NO}_{2}$ cross sections at $220 \mathrm{~K}$ and $298 \mathrm{~K}$ (for which linear correlation is $\sim 0.99$ ). The scaling factors (SFs) in the $435-485 \mathrm{~nm}$ fitting window are 0.79 $\left(\sigma_{298} \mathrm{~K}\right.$ orthogonalized relative to $\left.\sigma_{220 \mathrm{~K}}\right)$ and $1.26\left(\sigma_{220 \mathrm{~K}}\right.$ orthogonalized relative to $\sigma_{298} \mathrm{~K}$ ). We found perfect correlation $\left(R^{2}=1.000\right)$ between retrieved $\Delta \mathrm{SCD}^{220 \mathrm{~K}}$ and $\Delta \mathrm{SCD}^{298 \mathrm{~K}}$ using "standard" fitting (simultaneous fitting of $\sigma_{298} \mathrm{~K}$ and $\sigma_{220} \mathrm{~K}$ ) and "orthogonalized" fitting (simultaneous fitting of $\sigma_{220 \mathrm{~K}}$ and $\sigma_{298 \mathrm{~K}}$ orthogonalized relative to $\sigma_{220 \mathrm{~K}}$ and vice versa) for all sites. It is not clear what benefit $\mathrm{NO}_{2}$ cross section orthogonalization of one temperature relative to the other presents for $\mathrm{NO}_{2}$ retrieval from DS measurements at MFDOAS residual levels.

\section{Conclusions}

This paper presents a temperature sensitivity method (TESEM) to more accurately calculate the total $\mathrm{NO}_{2}$ col- 


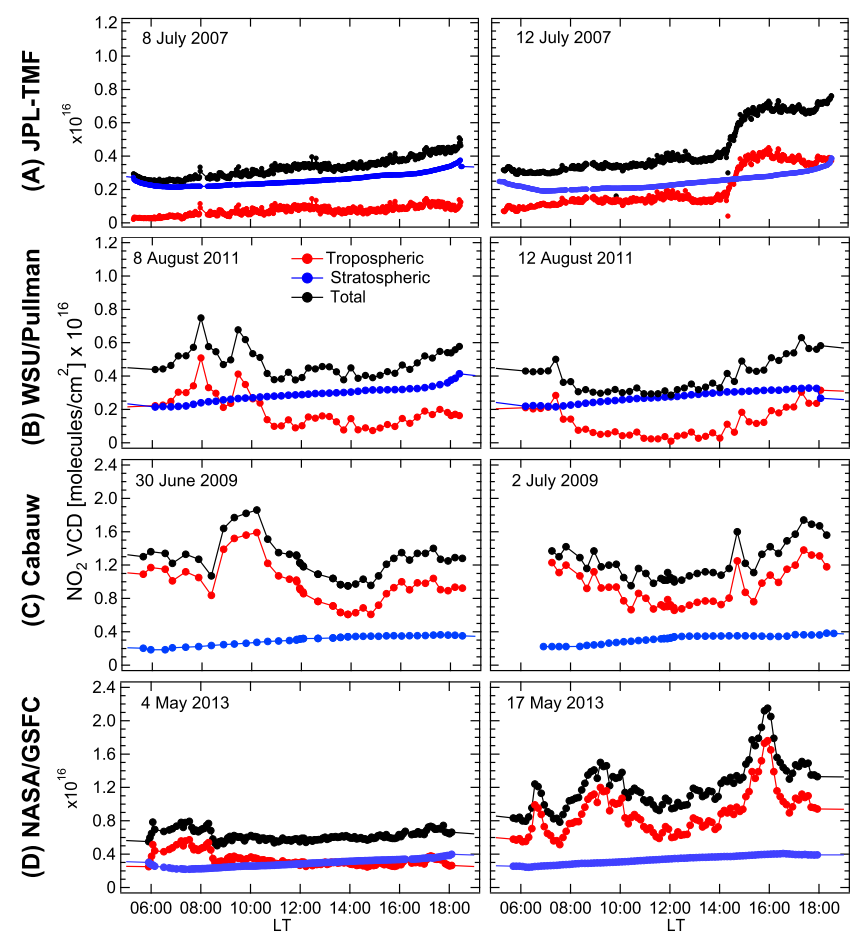

Figure 10. Total, stratospheric, and tropospheric $\mathrm{NO}_{2} \mathrm{VCD}$ derived from MFDOAS direct-sun measurements (435-485 nm) over two "clean" and two "polluted" sites: (a) JPL-TMF, CA (8 and 12 July 2007); (b) WSU/Pullman, WA (8 and 12 August 2001); (c) Cabauw, the Netherlands (30 June and 4 July 2009); and (d) NASA/GSFC Greenbelt, MD (4 and 17 May 2013).

umn and atmospheric slant $\mathrm{NO}_{2}$ profile-weighted temperature $(T)$, and to separate stratospheric and tropospheric columns from DS ground-based measurements using the retrieved $T$. TESEM is based on DOAS fitting of the linear temperature-dependent $\mathrm{NO}_{2}$ absorption cross section $(\sigma(T))$ regression model (Vandaele et al., 2003). The direct result of the DOAS spectral fitting is $\mathrm{NO}_{2}$ differential slant column density $(\triangle \mathrm{SCD})$ at the actual atmospheric $\mathrm{NO}_{2} T$. Atmospheric $\mathrm{NO}_{2} T$ is determined from the DOAS fitting results after SCD in the reference spectrum is estimated using MLE.

Since $\mathrm{NO}_{2}$ is mostly distributed between the lower troposphere and middle stratosphere and direct-sun measurements have almost equal sensitivity to stratospheric and tropospheric absorption at solar zenith angles $<75^{\circ}$, the retrieved total $\mathrm{NO}_{2} T$ can be represented as a sum of tropospheric fractions of the total $\mathrm{SCD}_{\mathrm{NO}_{2}}$. We use GMI CTM simulations to evaluate diurnal and seasonal variability of stratospheric and tropospheric $\mathrm{NO}_{2} T$ over two midlatitude sites in 2011. GMI simulations reveal that stratospheric $\mathrm{NO}_{2}$ $T$ over midlatitudes can be relatively accurately estimated (error $<3 \mathrm{~K}$ ) with the measured or simulated temperature at $27 \mathrm{~km}$ from April to October. The tropospheric $\mathrm{NO}_{2} T$ can be approximated by the surface temperature.
TESEM was applied to the Washington State University Multi-Function DOAS instrument (MFDOAS) measurements at four midlatitude locations with low and moderate $\mathrm{NO}_{2}$ anthropogenic emissions: (1) the Jet Propulsion Laboratory's Table Mountain Facility (JPL-TMF), CA $\left(34.38^{\circ} \mathrm{N} / 117.68^{\circ} \mathrm{W}\right)$; (2) Pullman, WA $\left(46.73^{\circ} \mathrm{N} / 117.17^{\circ} \mathrm{W}\right)$; (3) Greenbelt, MD $\left(38.99^{\circ} \mathrm{N} / 76.84^{\circ} \mathrm{W}\right)$; and (4) Cabauw, the Netherlands $\left(51.97^{\circ} \mathrm{N} / 4.93^{\circ} \mathrm{E}\right)$ during the summer months (July 2007, June-July 2009, July-August 2011, and May 2013) and fall/winter months (October 2011, and November 2012-February 2013). $\mathrm{NO}_{2} T$, total, stratospheric, and tropospheric $\mathrm{NO}_{2}$ vertical columns were determined over each site.

Traditionally, either $\sigma\left(\mathrm{NO}_{2}\right)$ is fitted at a single estimated $\mathrm{NO}_{2} T$ or two predetermined (stratospheric and tropospheric) $T$. Use of a single $T$ requires prior knowledge of the tropospheric-stratospheric $\mathrm{NO}_{2}$ columns partitioning in the measurement. In addition, it assumes that this partitioning is constant throughout the measurement period (sometimes months). Fitting of two $\sigma$ 's $\left(\mathrm{NO}_{2}\right)$ at fixed temperatures, typically 220 and $298 \mathrm{~K}$, assumes constant stratospheric and tropospheric $\mathrm{NO}_{2} T$ as a function of time. Neither assumption is correct, except as a convenient approximation. TESEM does not require prior knowledge of $\mathrm{NO}_{2}$ effective temperatures during the DOAS fitting stage and retrieves $T$ from the DOAS fitting results themselves.

For polluted regions, during high $\mathrm{NO}_{2}$ emission rates, the fixed-temperature method underestimates TESEM $\triangle$ SCD by up to $5-10 \%$, while for the times with lower emission rates, the fixed-temperature method overestimates TESEM $\triangle$ SCD by about $5-15 \%$. On average, the agreement is very good (within 1-6\%) for all sites and short-term campaigns during summer months. For sites with relatively constant $\mathrm{NO}_{2}$ emission rates or background $\mathrm{NO}_{2}$, the fixed-temperature method is fairly accurate, presuming that the effective temperature is estimated correctly. Agreement between total $\triangle \mathrm{SCD}$ resulting from the independent fitting of two $\mathrm{NO}_{2}$ absorption cross sections at 220 and $298 \mathrm{~K}$ and $\triangle \mathrm{SCD}$ from TESEM is very good $(<1 \%)$. In the case of cold months, the traditional methods will require fitting $\mathrm{NO}_{2}$ cross sections at the appropriate colder temperatures, as systematic errors are otherwise introduced. TESEM will need no adjustments.

Separation of stratospheric and tropospheric columns from DOAS measurements based on TESEM is mostly suited for measurements over regions where difference between total and stratospheric profile $\mathrm{NO}_{2}$ temperatures and $\mathrm{SCD}$ is large and for late spring/summer/early fall seasons, when $T_{27} \mathrm{~km}$ is representative of $\mathrm{NO}_{2} T^{\mathrm{STRAT}}$, and $T_{0} \mathrm{~km}$ is representative of $\mathrm{NO}_{2} T^{\mathrm{TROP}}$. In this study, separation was successful during late spring and summer months with the corresponding temperature differences between estimated $\mathrm{NO}_{2}$ total column $T$ and stratospheric $T$ of $17 \pm 12 \mathrm{~K}$ over JPL-TMF, $27 \pm 9 \mathrm{~K}$ over WSU/Pullman, $48 \pm 7 \mathrm{~K}$ over Cabauw, and $39 \pm 10 \mathrm{~K}$ over NASA/GSFC. 
Stratospheric and tropospheric $\mathrm{NO}_{2}$ columns derived from simpler DS measurements are of great value to model and satellite data validation. Currently only total VCD are retrieved from DS measurements. Tropospheric DS $\mathrm{NO}_{2}$ columns also can be used in MAX-DOAS inversion either as an initial guess or to "constrain" MAX-DOAS total tropospheric column retrieval. TESEM can also be applied to MAX-DOAS measurements to "subtract" stratospheric column from low elevation angles.

\section{The Supplement related to this article is available online at doi:10.5194/amt-7-4299-2014-supplement.}

Acknowledgements. The development and deployment of MFDOAS were supported by the National Aeronautics and Space Administration grants to Washington State University (NNX09AJ28G and NNG05GR56G). We are grateful for the institutional support from JPL Table Mountain Facility (Stanley Sander and co-workers), GSFC (Kent McCullough, Nader Abuhassan), Cabauw (CINDI organizers at KNMI), and WSU (Kurt Hutchinson and Gary Held), where the field measurements were taken.

Edited by: U. Friess

\section{References}

Bey, I., Jacob, D. J., Yantosca, R. M., Logan, J. A., Field, B. D., Fiore, A. M., Li, Q., Liu, H. Y., Mickley, L. J., and Schultz, M. G.: Global modeling of tropospheric chemistry with assimilated meteorology: model description and evaluation, J. Geophys. Res.-Atmos., 106, 23073-23095, doi:10.1029/2001JD000807, 2001.

Brewer, A. W., Mcelroy, C. T., and Kerr, J. B.: Nitrogen dioxide concentrations in the atmosphere, Nature, 246, 129-133, doi:10.1038/246129a0, 1973.

Butz, A., Bösch, H., Camy-Peyret, C., Chipperfield, M., Dorf, M., Dufour, G., Grunow, K., Jeseck, P., Kühl, S., Payan, S., Pepin, I., Pukite, J., Rozanov, A., von Savigny, C., Sioris, C., Wagner, T., Weidner, F., and Pfeilsticker, K.: Inter-comparison of stratospheric $\mathrm{O}_{3}$ and $\mathrm{NO}_{2}$ abundances retrieved from balloon borne direct sun observations and Envisat/SCIAMACHY limb measurements, Atmos. Chem. Phys., 6, 1293-1314, doi:10.5194/acp-61293-2006, 2006.

Cede, A., Herman, J., Richter, A., Krotkov, N., and Burrows, J.: Measurements of nitrogen dioxide total column amounts using a Brewer double spectrophotometer in direct Sun mode, J. Geophys. Res., 111, D05304, doi:10.1029/2005JD006585, 2006.

Chance, K. V. and Spurr, R. J. D.: Ring effect studies: Rayleigh scattering, including molecular parameters for rotational Raman scattering, and the Fraunhofer spectrum, Appl. Optics, 36, 52245230, doi:10.1364/AO.36.005224, 1997.

Clémer, K., Van Roozendael, M., Fayt, C., Hendrick, F., Hermans, C., Pinardi, G., Spurr, R., Wang, P., and De Mazière, M.:
Multiple wavelength retrieval of tropospheric aerosol optical properties from MAXDOAS measurements in Beijing, Atmos. Meas. Tech., 3, 863-878, doi:10.5194/amt-3-863-2010, 2010.

Danckaert, T., Fayt, C., Van Roozendael, M., De Smedt, I., Letocart, V., Merlaud, A., and Pinardi, G.: QDOAS Software User Manual, Belgian Institute for Space Aeronomy (BIRA-IASB), 2012.

Douglass, A. R., Stolarski, R. S., Strahan, S. E., and Connell, P. S.: Radicals and reservoirs in the GMI chemistry and transport model: comparison to measurements, J. Geophys. Res.-Atmos., 109, D16302, doi:10.1029/2004JD004632, 2004.

Duncan, B. N., Strahan, S. E., Yoshida, Y., Steenrod, S. D., and Livesey, N.: Model study of the cross-tropopause transport of biomass burning pollution, Atmos. Chem. Phys., 7, 3713-3736, doi:10.5194/acp-7-3713-2007, 2007.

Fish, D. J. and Jones, R. L.: Rotational Raman scattering and the ring effect in zenith-sky spectra, Geophys. Res. Lett., 22, 811814, 1995.

Frieß, U., Monks, P. S., Remedios, J. J., Rozanov, A., Sinreich, R., Wagner, T., and Platt, U.: MAX-DOAS O4 measurements: a new technique to derive information on atmospheric aerosols: 2. Modeling studies, J. Geophys. Res., 111, D14203, doi:10.1029/2005JD006618, 2006.

Grainger, J. F. and Ring, J.: Anomalous Fraunhofer line profiles, Nature, 193, 762, doi:10.1038/193762a0, 1962.

Harder, J. W., Brault, J. W., Johnston, P. V., and Mount, G. H.: Temperature dependent $\mathrm{NO}_{2}$ cross sections at high spectral resolution, J. Geophys. Res., 102, 3861, doi:10.1029/96JD03086, 1997.

Heckel, A., Richter, A., Tarsu, T., Wittrock, F., Hak, C., Pundt, I., Junkermann, W., and Burrows, J. P.: MAX-DOAS measurements of formaldehyde in the Po-Valley, Atmos. Chem. Phys., 5, 909918, doi:10.5194/acp-5-909-2005, 2005.

Hendrick, F., Barret, B., Van Roozendael, M., Boesch, H., Butz, A., De Mazière, M., Goutail, F., Hermans, C., Lambert, J.-C., Pfeilsticker, K., and Pommereau, J.-P.: Retrieval of nitrogen dioxide stratospheric profiles from ground-based zenith-sky UV-visible observations: validation of the technique through correlative comparisons, Atmos. Chem. Phys., 4, 2091-2106, doi:10.5194/acp-4-2091-2004, 2004.

Hendrick, F., Mahieu, E., Bodeker, G. E., Boersma, K. F., Chipperfield, M. P., De Mazière, M., De Smedt, I., Demoulin, P., Fayt, C., Hermans, C., Kreher, K., Lejeune, B., Pinardi, G., Servais, C., Stübi, R., van der A, R., Vernier, J.-P., and Van Roozendael, M.: Analysis of stratospheric $\mathrm{NO}_{2}$ trends above Jungfraujoch using ground-based UV-visible, FTIR, and satellite nadir observations, Atmos. Chem. Phys., 12, 8851-8864, doi:10.5194/acp-12-88512012, 2012.

Herman, J., Cede, A., Spinei, E., Mount, G., Tzortziou, M., and Abuhassan, N.: $\mathrm{NO}_{2}$ column amounts from groundbased Pandora and MFDOAS spectrometers using the direct-sun DOAS technique: intercomparisons and application to OMI validation, J. Geophys. Res., 114, D13307, doi:10.1029/2009JD011848, 2009.

Irie, H., Kanaya, Y., Akimoto, H., Iwabuchi, H., Shimizu, A., and Aoki, K.: First retrieval of tropospheric aerosol profiles using MAX-DOAS and comparison with lidar and sky radiometer measurements, Atmos. Chem. Phys., 8, 341-350, doi:10.5194/acp-8341-2008, 2008. 
Irie, H., Kanaya, Y., Akimoto, H., Iwabuchi, H., Shimizu, A., and Aoki, K.: Dual-wavelength aerosol vertical profile measurements by MAX-DOAS at Tsukuba, Japan, Atmos. Chem. Phys., 9, 2741-2749, doi:10.5194/acp-9-2741-2009, 2009.

Kattawar, G. W., Young, A. T., and Humphreys, T. J.: Inelastic scattering in planetary atmospheres. I - The Ring effect, without aerosols, Astrophys. J., 243, 1049-1057, 1981.

Kritten, L., Butz, A., Dorf, M., Deutschmann, T., Kühl, S., PradosRoman, C., Pukite, J., Rozanov, A., Schofield, R., and Pfeilsticker, K.: Time dependent profile retrieval of UV/vis absorbing radicals from balloon-borne limb measurements - a case study on $\mathrm{NO}_{2}$ and $\mathrm{O}_{3}$, Atmos. Meas. Tech., 3, 933-946, doi:10.5194/amt3-933-2010, 2010.

Li, X., Brauers, T., Shao, M., Garland, R. M., Wagner, T., Deutschmann, T., and Wahner, A.: MAX-DOAS measurements in southern China: 1. automated aerosol profile retrieval using oxygen dimers absorptions, Atmos. Chem. Phys. Discuss., 8, 17661-17690, doi:10.5194/acpd-8-17661-2008, 2008.

Li, X., Brauers, T., Shao, M., Garland, R. M., Wagner, T., Deutschmann, T., and Wahner, A.: MAX-DOAS measurements in southern China: retrieval of aerosol extinctions and validation using ground-based in-situ data, Atmos. Chem. Phys., 10, 2079 2089, doi:10.5194/acp-10-2079-2010, 2010.

Li, X., Brauers, T., Hofzumahaus, A., Lu, K., Li, Y. P., Shao, M., Wagner, T., and Wahner, A.: MAX-DOAS measurements of $\mathrm{NO}_{2}, \mathrm{HCHO}$ and $\mathrm{CHOCHO}$ at a rural site in Southern China, Atmos. Chem. Phys., 13, 2133-2151, doi:10.5194/acp-13-21332013, 2013.

Malicet, J., Daumont, D., Charbonnier, J., Parisse, C., Chakir, A., and Brion, J.: Ozone UV spectroscopy. II. Absorption crosssections and temperature dependence, J. Atmos. Chem., 21, 263 273, doi:10.1007/BF00696758, 1995.

Martin, R. V., Jacob, D. J., Chance, K., Kurosu, T. P., Palmer, P. I., and Evans, M. J.: Global inventory of nitrogen oxide emissions constrained by space-based observations of $\mathrm{NO}_{2}$ columns, J. Geophys. Res., 108, 4537, doi:10.1029/2003JD003453, 2003.

McKenzie, R. L., Johnston, P. V., McElroy, C. T., Kerr, J. B., and Solomon, S.: Altitude distributions of stratospheric constituents from ground-based measurements at twilight, J. Geophys. Res., 96, 15499, doi:10.1029/91JD01361, 1991.

Mohnen, V. A.: The challenge of acid rain, Sci. Am., 259, 30-38, 1988.

Mount, G. H., Sanders, R. W., Schmeltekopf, A. L., and Solomon, S.: Visible spectroscopy at McMurdo Station, Antarctica 1. Overview and daily variations of $\mathrm{NO}_{2}$ and $\mathrm{O}_{3}$, Austral Spring, 1986, J. Geophys. Res., 92, 8320-8328, doi:10.1029/JD092iD07p08320, 1987.

Noxon, J. F.: Nitrogen dioxide in the stratosphere and troposphere measured by ground-based absorption spectroscopy, Science, 189, 547-549, doi:10.1126/science.189.4202.547, 1975.

Noxon, J. F., Whipple, E. C., and Hyde, R. S.: Stratospheric $\mathrm{NO}_{2}: 1$. Observational method and behavior at mid-latitude, J. Geophys. Res., 84, 5047, doi:10.1029/JC084iC08p05047, 1979.

Olivier, J. G. J., Bouwman, A. F., Van der Hoek, K. W., and Berdowski, J. J. M.: Global air emission inventories for anthropogenic sources of $\mathrm{NO}_{\mathrm{x}}, \mathrm{NH}_{3}$ and $\mathrm{N}_{2} \mathrm{O}$ in 1990, Environ. Pollut., 102, 135-148, doi:10.1016/S0269-7491(98)80026-2, 1998.

Parrish, D. D., Kondo, Y., Cooper, O. R., Brock, C. A., Jaffe, D. A., Trainer, M., Ogawa, T., Hübler, G. and Fehsenfeld, F. C.:
Intercontinental Transport and Chemical Transformation 2002 (ITCT 2K2) and Pacific Exploration of Asian Continental Emission (PEACE) experiments: an overview of the 2002 winter and spring intensives, J. Geophys. Res., 109, D23S01, doi:10.1029/2004JD004980, 2004.

Piters, A. J. M., Boersma, K. F., Kroon, M., Hains, J. C., Van Roozendael, M., Wittrock, F., Abuhassan, N., Adams, C., Akrami, M., Allaart, M. A. F., Apituley, A., Beirle, S., Bergwerff, J. B., Berkhout, A. J. C., Brunner, D., Cede, A., Chong, J., Clémer, K., Fayt, C., Frieß, U., Gast, L. F. L., GilOjeda, M., Goutail, F., Graves, R., Griesfeller, A., Großmann, K., Hemerijckx, G., Hendrick, F., Henzing, B., Herman, J., Hermans, C., Hoexum, M., van der Hoff, G. R., Irie, H., Johnston, P. V., Kanaya, Y., Kim, Y. J., Klein Baltink, H., Kreher, K., de Leeuw, G., Leigh, R., Merlaud, A., Moerman, M. M., Monks, P. S., Mount, G. H., Navarro-Comas, M., Oetjen, H., Pazmino, A., Perez-Camacho, M., Peters, E., du Piesanie, A., Pinardi, G., Puentedura, O., Richter, A., Roscoe, H. K., Schönhardt, A., Schwarzenbach, B., Shaiganfar, R., Sluis, W., Spinei, E., Stolk, A. P., Strong, K., Swart, D. P. J., Takashima, H., Vlemmix, T., Vrekoussis, M., Wagner, T., Whyte, C., Wilson, K. M., Yela, M., Yilmaz, S., Zieger, P., and Zhou, Y.: The Cabauw Intercomparison campaign for Nitrogen Dioxide measuring Instruments (CINDI): design, execution, and early results, Atmos. Meas. Tech., 5, 457-485, doi:10.5194/amt-5-457-2012, 2012.

Plane, J. and Smith, N.: Atmospheric monitoring by differential optical absorption spectroscopy, in: Spectroscopy in Environmental Science, Vol. 24, Wiley, Chichester, 223-262, 1995.

Platt, U.: Differential Optical Absorption Spectroscopy (DOAS), in: Air monitoring by spectroscopic techniques, edited by: Sigrist, M. W., Vol. 127, Wiley-IEEE, New York, p. 531, 1994.

Platt, U., Perner, D., and Pätz, H. W.: Simultaneous measurement of atmospheric $\mathrm{CH}_{2} \mathrm{O}, \mathrm{O}_{3}$, and $\mathrm{NO}_{2}$ by differential optical absorption, J. Geophys. Res., 84, 6329, doi:10.1029/JC084iC10p06329, 1979.

Pommereau, J.-P. and Piquard, J.: Ozone and nitrogen dioxide vertical distributions by UV-visible solar occultation from balloons, Geophys. Res. Lett., 21, 1227-1230, doi:10.1029/94GL00389, 1994.

Preston, K. E., Jones, R. L., and Roscoe, H. K.: Retrieval of $\mathrm{NO}_{2}$ vertical profiles from ground-based UV-visible measurements: method and validation, J. Geophys. Res., 102, 19089-19097, 1997.

Richter, A.: Absorptionsspektroskopische Messungen stratospharischer Spurengase uber Bremen $53^{\circ} \mathrm{N}$, Ph.D. thesis, University of Bremen, Germany, available at: http://www.doasbremen.de/publications.htm\#pPhD (last access: 19 May 2014), 1997.

Rienecker, M. M., Suarez, M., Todling, R., Bacmeister, J., Takacs, L., Liu, H.-C., Gu, W., Sienkiewicz, M., Koster, R., Gelaro, R., Stajner, I., and Nielsen, J.: The GEOS-5 data assimilation system - documentation of versions 5.0.1, 5.1.0, and 5.2.0, in: Technical Report Series on Global Modeling and Data Assimilation, Vol. 27., 2008.

Rothman, L. S., Gordon, I. E., Barber, R. J., Dothe, H., Gamache, R. R., Goldman, A., Perevalov, V. I., Tashkun, S. A. and Tennyson, J.: HITEMP, the high-temperature molecular 
spectroscopic database, J. Quant. Spectr. Radiat. Trans., 111, 2139-2150, doi:10.1016/j.jqsrt.2010.05.001, 2010.

Sinreich, R., Friess, U., Wagner, T., and Platt, U.: Multi axis differential optical absorption spectroscopy (MAX-DOAS) of gas and aerosol distributions, Faraday Discuss., 130, 519-524, 2005.

Solomon, S., Schmeltekopf, A. L., and Sanders, R. W.: On the interpretation of zenith sky absorption measurements, J. Geophys. Res., 92, 8311-8319, doi:10.1029/JD092iD07p08311, 1987.

Spinei, E., Carn, S., Krotkov, N., Mount, G. H., Yang, K., and Krueger, A.: Validation of $\mathrm{OMI} \mathrm{SO}_{2}$ measurements in the Okmok volcanic cloud over Pullman, WA, July 2008, J. Geophys. Res, 115, D00L08, doi:10.1029/2009JD013492, 2010.

Spinei, E., Mount, G. H., Abuhassan, N., Cede, A., Herman, J., Van Roozendael, M., Clemer, K., Fayt, C., Hendrick, F., Goutail, F., Griesfeller, A., Pazmino, A., and Piters, A. J. M.: Total and tropospheric $\mathrm{NO}_{2}$ column measurements using direct sun, zenith sky and MAX-DOAS techniques during the CINDI campaign, Atmos. Meas. Tech., in preparation, 2014.

Strahan, S. E., Duncan, B. N., and Hoor, P.: Observationally derived transport diagnostics for the lowermost stratosphere and their application to the GMI chemistry and transport model, Atmos. Chem. Phys., 7, 2435-2445, doi:10.5194/acp-7-2435-2007, 2007.

Vandaele, A., Hermans, C., Simon, P., Carleer, M., Colin, R., Fally, S., Mérienne, M.-F., Jenouvrier, A., and Coquart, B.: Measurements of the $\mathrm{NO}_{2}$ absorption cross-section from $42000 \mathrm{~cm}^{-1}$ to $10000 \mathrm{~cm}^{-1}(238-1000 \mathrm{~nm})$ at $220 \mathrm{~K}$ and $294 \mathrm{~K}$, J. Quant. Spectrosc. Ra., 59, 171-184, doi:10.1016/S0022-4073(97)00168-4, 1998.

Vandaele, A. C., Hermans, C., Fally, S., Carleer, M., Mérienne, M.F., Jenouvrier, A., Coquart, B., and Colin, R.: Absorption crosssections of $\mathrm{NO}_{2}$ : simulation of temperature and pressure effects, J. Quant. Spectrosc. Ra., 76, 373-391, doi:10.1016/S00224073(02)00064-X, 2003.
Wagner, T., Dix, B., Friedeburg, C. v., Frieß, U., Sanghavi, S., Sinreich, R., and Platt, U.: MAX-DOAS O4 measurements: a new technique to derive information on atmospheric aerosols - principles and information content, J. Geophys. Res.-Atmos., 109, 22205, doi:10.1029/2004JD004904, 2004.

Wagner, T., Burrows, J. P., Deutschmann, T., Dix, B., von Friedeburg, C., Frieß, U., Hendrick, F., Heue, K.-P., Irie, H., Iwabuchi, H., Kanaya, Y., Keller, J., McLinden, C. A., Oetjen, H., Palazzi, E., Petritoli, A., Platt, U., Postylyakov, O., Pukite, J., Richter, A., van Roozendael, M., Rozanov, A., Rozanov, V., Sinreich, R., Sanghavi, S., and Wittrock, F.: Comparison of box-airmass-factors and radiances for Multiple-Axis Differential Optical Absorption Spectroscopy (MAX-DOAS) geometries calculated from different UV/visible radiative transfer models, Atmos. Chem. Phys., 7, 1809-1833, doi:10.5194/acp-7-1809-2007, 2007.

Wagner, T., Ibrahim, O., Shaiganfar, R., and Platt, U.: Mobile MAX-DOAS observations of tropospheric trace gases, Atmos. Meas. Tech., 3, 129-140, doi:10.5194/amt-3-129-2010, 2010.

Wang, S., Pongetti, T., Sander, S. P., Spinei, E., Mount, G. H., Cede, A., and Herman, J.: Direct sun measurements of $\mathrm{NO}_{2}$ column abundances from Table Mountain, California: intercomparison of low and high resolution spectrometers, J. Geophys. Res., 115, D13305, doi:10.1029/2009JD013503, 2010.

Wenig, M., Spichtinger, N., Stohl, A., Held, G., Beirle, S., Wagner, T., Jähne, B., and Platt, U.: Intercontinental transport of nitrogen oxide pollution plumes, Atmos. Chem. Phys., 3, 387-393, doi:10.5194/acp-3-387-2003, 2003. 